УДК 581.4(571.63)

dx.doi.org/10.24866/7444-4911-7/20-38

\title{
Краеведческий материал для изучения темы «Видоизменения побегов» в курсе ботаники общеобразовательной школы в Приморском крае
}

\author{
В.В. Рыбакова, А.С. Коляда \\ Дальневосточный фредеральный университет. Филиал в г. Уссурийске (Школа педагогики)
}

В статье приводятся сведения о видоизмененияхпобегов сосудистых растений Приморского края, которые можно использовать в преподавании ботаники в общеобразовательной школе.

Ключевые слова: ботаника, метаморфозы побегов, краеведческий материал, Приморский край.

Побег, находясь в изменчивой воздушной среде и испытывая многостороннее действие с её стороны, может подвергаться значительным морфологическим изменениям. При этом, учитывая единство побега как органа, видоизменению подвергаются одновременно и стебли, и листья. Лишь в некоторых случаях метаморфизируются только листья.

Для растений Приморского края характерно значительное разнообразие видоизменений побега. Это даёт возможность привлекать обширный краеведческий материал при изучении данной темы в курсе ботаники общеобразовательной школы.

В настоящей статье приводится информация о видоизменениях побегов травянистых и древесных растений Приморского края, которые рассматриваются с точки зрения функции, которую они выполняют.

\section{1. Метаморфозы, служащие для регуляции процессов жизнедеятельности растений}

Важнейшим процессом, который растения регулируют путем образования метаморфозов побегов, является транспирация (испарение воды). Излишняя транспирация вредна растениям, поэтому виды, произрастающие в условиях недостатка влаги, вынуждены использовать различные механизмы, в т.ч. морфологические, направленные на её сокращение.

\section{1. Филлокладии}

Филлокладии представляют собой уплощенные листоподобные или игольчатые побеги, выполняющие функцию фотосинтеза и способствующие уменьшению испаряющей поверхности. Настоящие листья в этом случае редуцированы, обычно имеют вид чешуй. Поскольку на стеблях устьиц гораздо меньше, чем на листе, интенсивность транспирации резко снижается. Одно из свидетельств побегового происхождения филлокладий - образование на них цветков и соцветий. Из растений Приморского края фриллокладии свойственны видам спаржы (AsparagusL.) из семейства Спаржевые (AsparagaceaeJuss.). В Приморье произрастают два вида этого рода - спаржа шобериевидная( $A$. schoberioidesKunth) и маловетвистая (A. oligoclonosMaxim.) (рис. 1).

Филлокладии широко распространённой в крае спаржи шобериевиднойзёленые, игольчатые, 2,2 см длины и 0,8 см ширины, по краю с едва заметными зубцами, по 3(4-5) в мутовке (рис. 1), в поперечном сечении 3-гранные (в отличие от спаржи маловетвистой, имеющей многогранные филлокладии). Расположение в узле специфическое: обычно два филлокладия расположены по одной прямой, а третья - перпендикулярно им. 

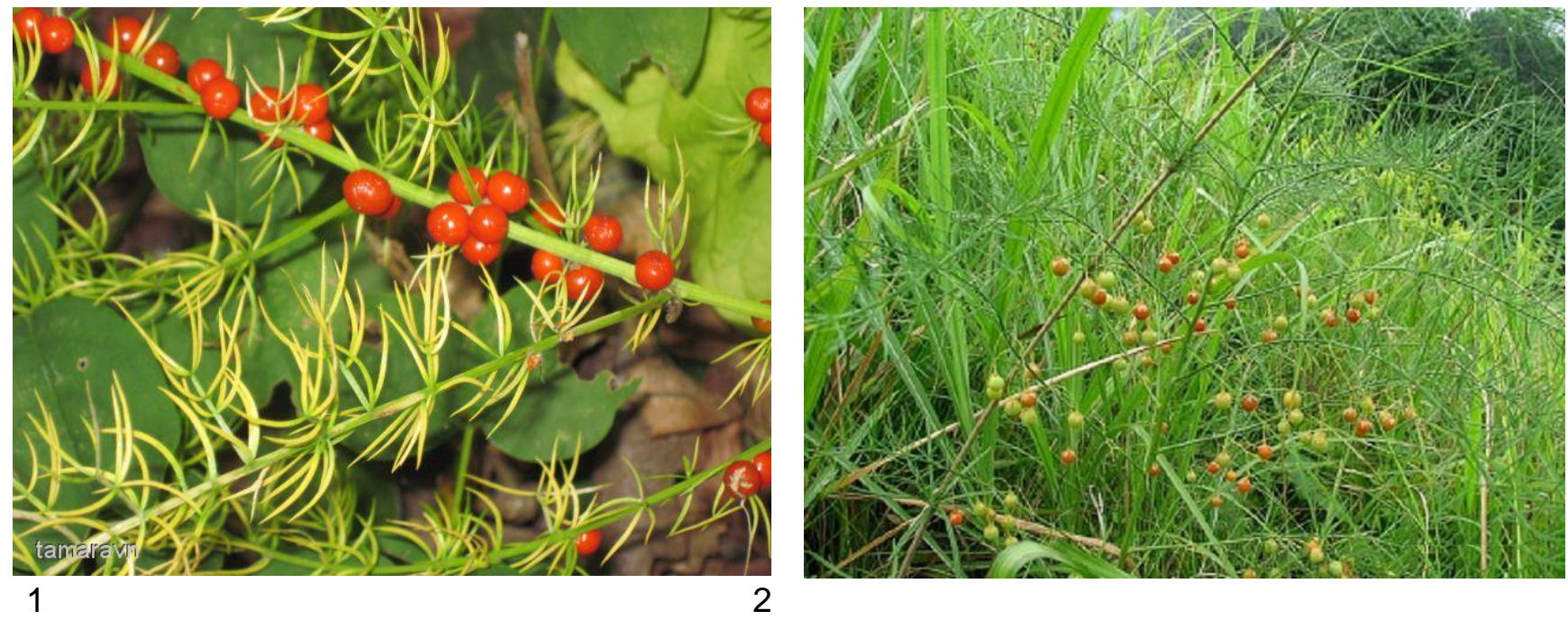

Рис. 1. Спаржа шобериевидная (1, https://all-begonias-tamaravn.blogspot.com) и маловетвистая (2, https://www.asienda.ru/plants)

\section{2. Колючки}

В условиях недостаточного водоснабжения побеги могут видоизменяться в колючки, в результате чего резко уменьшается испаряющая поверхность. Будучи заострёнными образованиями, колючки выполняют и вторичную защитную функцию.

О стеблевом происхождении колючки свидетельствует ряд фракторов: ветвление - оно ярко выражено, например, у гледичии (Gleditsia); анатомическое строение, которое повторяет анатомическое строение стебля; при помещении в условия повышенной влажности колючки некоторых растений развиваются в нормальные побеги.

Колючки могут быть видоизменением побега в целом, видоизменением листа либо прилистников.

Колючки побегового происхождения

У груши, яблони, сливы, облепихи, жёстера в колючку видоизменяется верхушка побега, у боярышника - укороченные побеги (Бавтуто, Ерей, 2002).

Семейство Розовые - RosaceaeJuss.

Род Боярышник - CrataegusL. Колючки боярышника Максимовича (C. maximowicziiC.K.Schneid.), боярышника перистонадрезанного (C. pinnatifidaBunge) серой окраски, короткие (до 2-2,5 см длины), жёсткие (рис. 2). Изначально достаточно тонкие, они со временем несколько утолщаются. В основании колючек заметны мелкие почки.

Род Груша - PyrusL.Единственный представитель рода - груша уссурийская ( $P$. ussuriensisMaxim.) - имеет колючки до 2,5 см длины, сероватые или серо-коричневые (рис. 2).Как и у колючек боярышников, на колючках груши можно заметить мелкие почки, которые в некоторых случаях прорастают и образуют боковые укороченные побеги (рис. 3).

Род Плоскосемянник - PrinsepiaRoyle. Колючки плоскосемянника китайского (P. chinensis (Oliv.)Oliv.exBean) простые, до 1(2) см длины, часто изогнутые книзу, располагаются в узлах (рис. 3).

Семейство Лоховые - ElaeagnaceaeJuss.

Род Облепиха - HippophaeL. Выращиваемая в качестве плодового растения облепиха крушиновидная (H. rhamnoidesL.) имеет колючки, которыми заканчивается каждый ростовый побег.

Семейство Крушиновые, Жёстеровые - RhamnaceaeJuss.

Род Жёстер - RhamnusL. Колючки заканчивают побег. У жёстерауссурийского (Rh. ussuriensisYa.Vasssil.) колючкой заканчивается каждый ростовый побег (рис. 2), у жёстерадиамантского (Rh. diamantiacaNakai) лишь некоторые побеги заканчиваются колючками. 

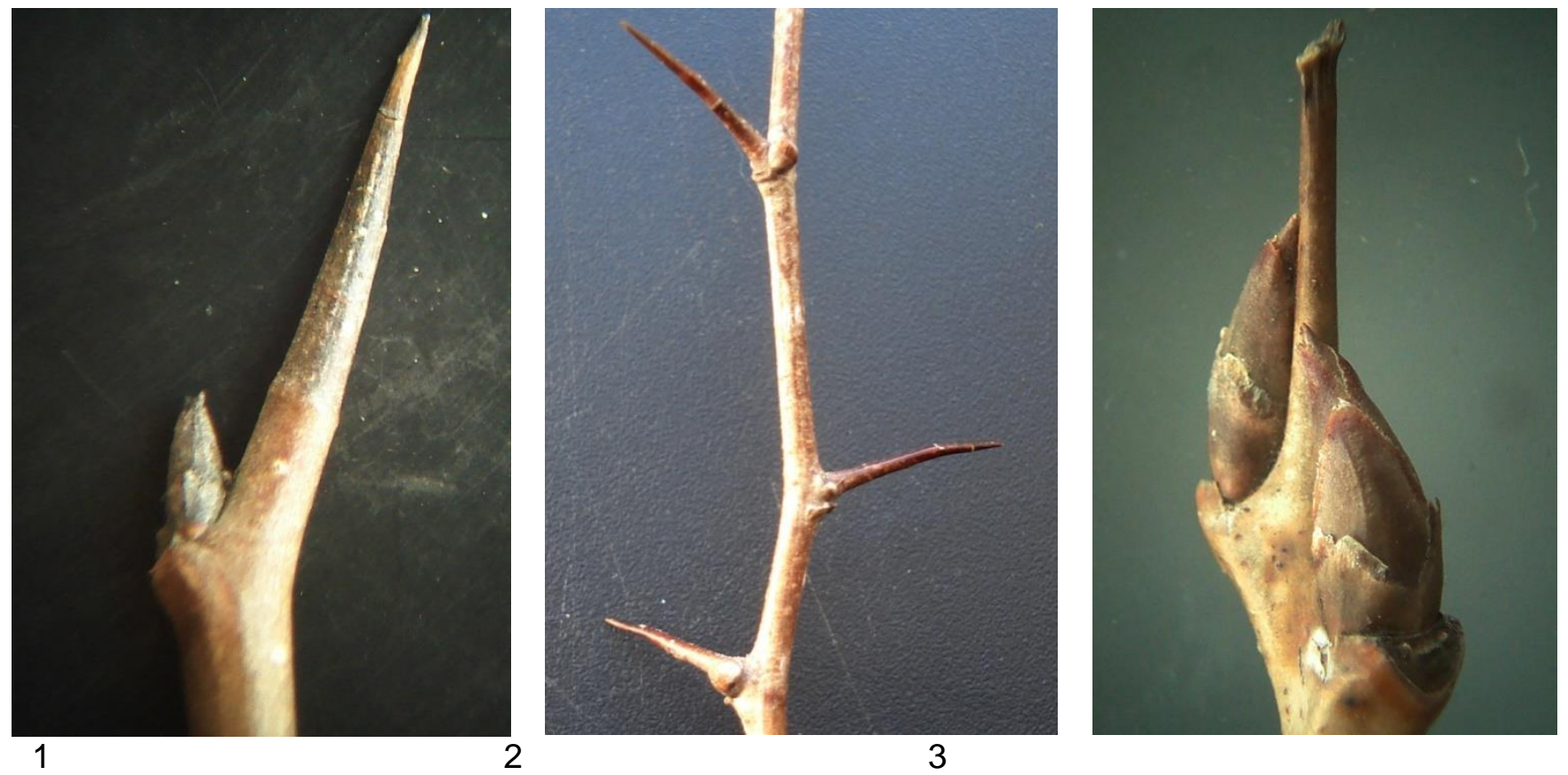

3

Рис. 2. Колючки груши уссурийской (1, фото А. Коляды), боярышника перистонадрезанного (2, фото В. Рыбаковой), жёстера уссурийского (3, фото А. Коляды)
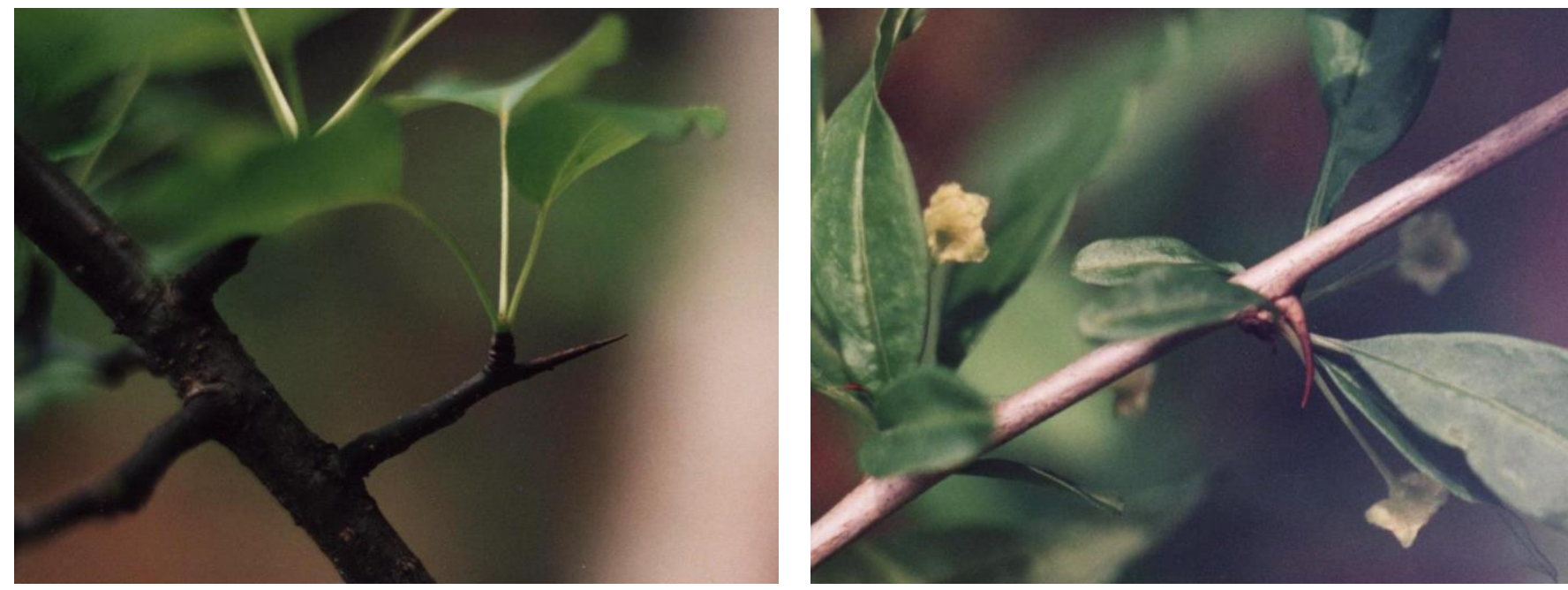

1

2

Рис. 3. Колючка с боковым побегом груши уссурийской (1, фоото В. Рыбаковой); колючка плоскосемянника китайского (2, фото А. Коляды)

\section{Колючки листового происхождения}

Семейство Барбарисовые - BerberidaceaeJuss.Колючки барбариса амурского $(B$. amurensisRupr.) располагаются в узлах, 3(1-5)-рассечённые (рис. 4), до 2-2,5 см длины и 0,2 см в диаметре. В поперечном сечении округлые, с нижней стороны имеется выемка. В начале развития колючки мягкие, зелёные, к осени твердеют, усыхают и приобретают серую окраску.

Анатомическое строение поперечного среза колючки имеет сходство со строением листа. Под эпидермой располагается мощный слой клеток склеренхимы. Центральную часть занимает основная ткань (соответствует мезофиллу, нами отмечались хлоропласты в клетках). В центре располагается ряд проводящих пучков с крупными склеренхимными обкладками. 


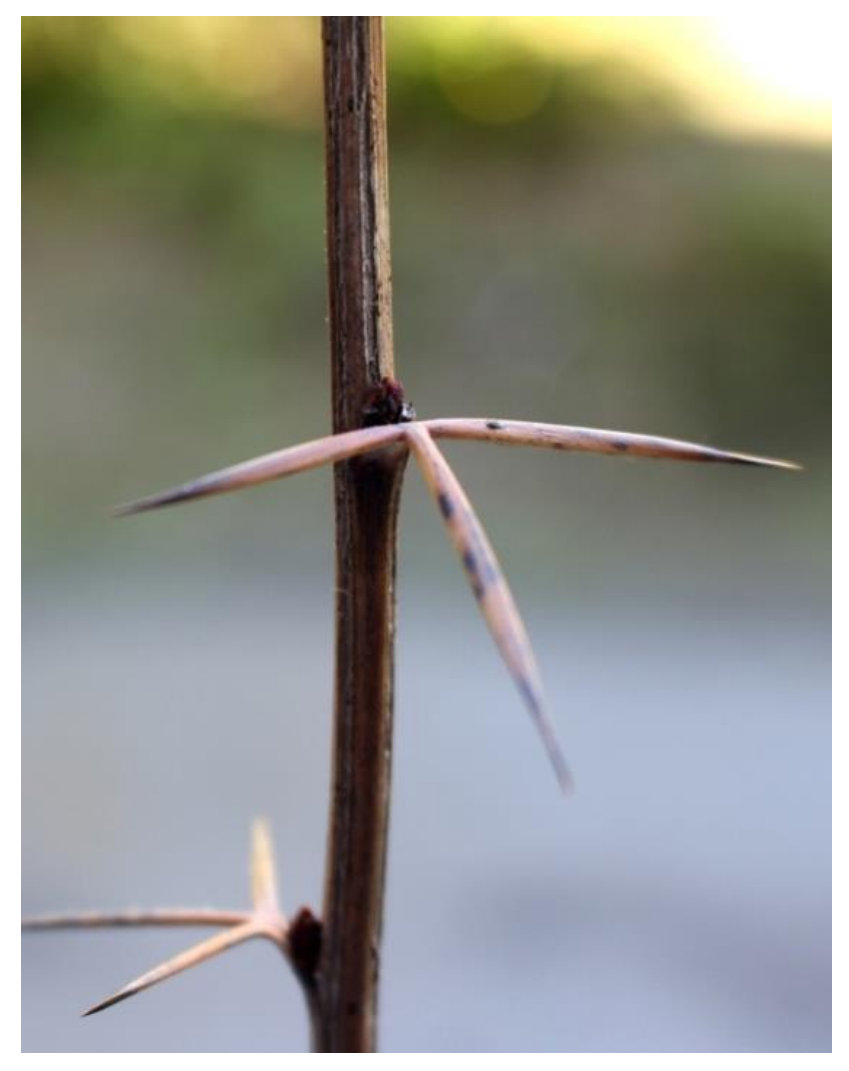

Рис. 4. Колючки барбариса амурского (фото А. Коляды)

Семейство Бобовые - FabaceaeLindl.

Колючки - видоизменения прилистников

Род Робиния - RobiniaL. У культивируемой в Приморском крае в качестве декоративного растения робиния ложноакациевой ( $R$. pseudoacaciaL.) колючки парные, размеры их варьируют от 0,5 до 1,5(2) см длины, в начале развития зелёные, мягкие, впоследствии буреют, к осени становятся серыми, усыхают (рис. 5). Сохраняются на ветвях и молодых стволах.На поперечном срезе колючки можно увидеть покровную ткань, представленную двухслойной эпидермой, под которой окружностью из 6-7 слоев клеток располагается склеренхима, придающая колючке прочность. Внутреннюю часть колючки занимает однородная ткань (аналог мезофилла), в которой заметны проводящие пучки, наиболее крупный из которых находится в центре.

Род Карагана - CaraganaFabr. Карагана древовидная (C. arborescensLam.). Колючки этого культивируемого как декоративное растение кустарника (реже деревца) достаточно мелкие, до 0,5 см длины, игольчатые, парные, направлены кверху (рис. 5).Тонкие колючки имеются также у караганы уссурийской (C. ussuriensis (Regel) Pojark.).Они узкотреугольные или шиповидные (рис. 5), часто твердеющие.

\section{3. Ловчие аппараты насекомоядных растений}

Листья некоторых растений, видоизменяясь, образуют приспособления для поимки насекомых, служащих дополнительным источником азотного питания.

В Приморье произрастают представители 2 семейств насекомоядных растений - Росянковые (DroseraceaeDC.) и Пузырчатковые (LentibulariaceaeRich.)

Семейство Росянковые представлено двумя родами: в один род, включающий водные растения (альдрованда, AldrovandaL.), входит один вид, альдрованда пузырчатая ( $A$. vesiculosaL.); в другой, который представлен наземными болотными растениями (росянка, DroseraL.) - два вида: росянка круглолистная (D.rotundifoliaL.) и английская (D. anglicaHuds.).

Альдрованда (рис. 6) обитает в пресных водоёмах, на болотах. Она улавливает насекомых с помощью видоизмененных листьев: ловчий аппарат состоит из двух половинок, на которые разделена листовая пластинка. При раздражении чувствительных волосков проис- 
ходит смыкание половинок аппарата, в результате чего добыча (мелкие водные животные, в т.ч. мальки рыб) оказывается пойманной.
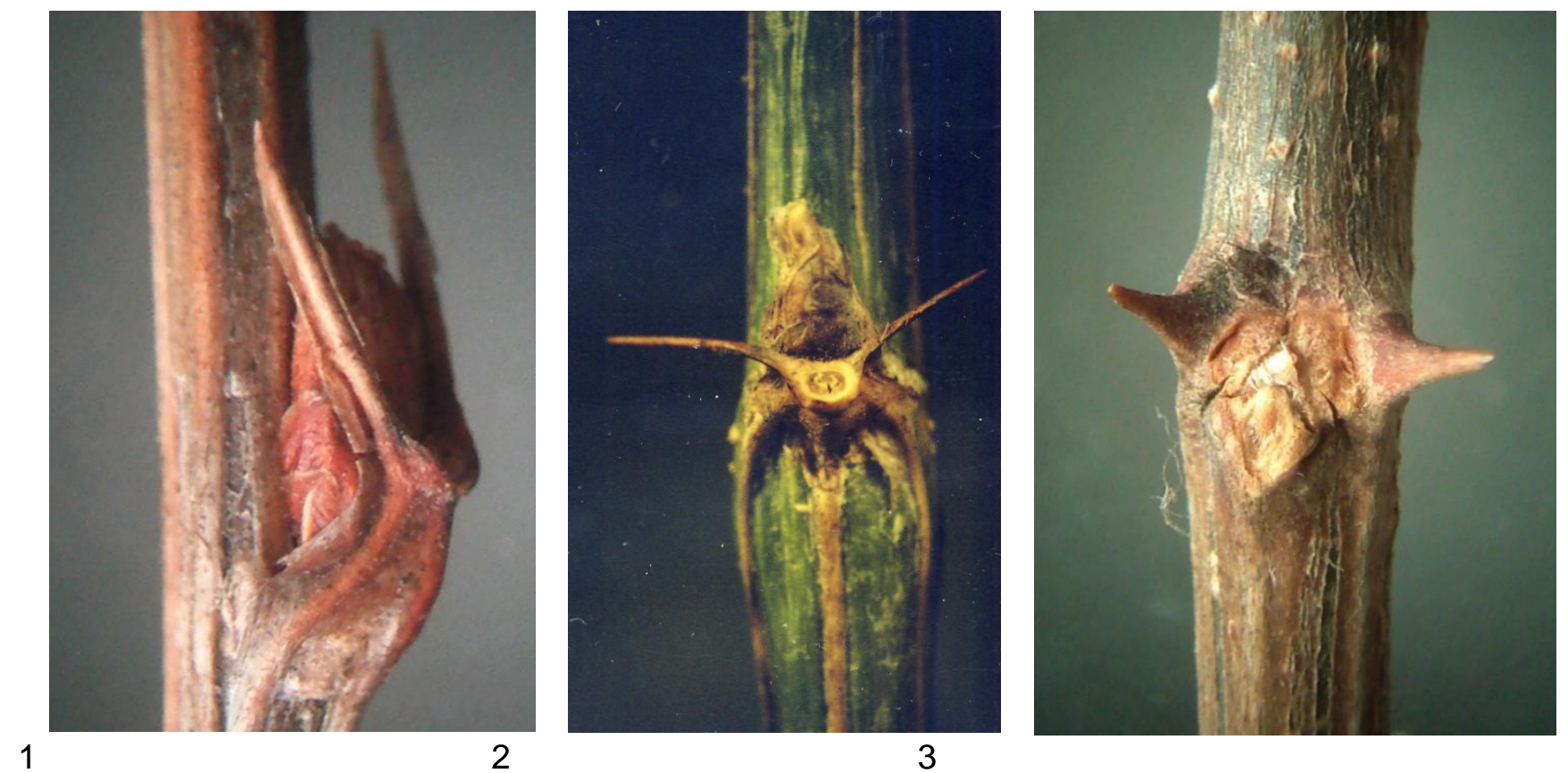

Рис. 5. Колючки прилистникового происхождения караганы уссурийской (1), караганы древовидной (2), робинии ложноакациевой (3) (фото А. Коляды)
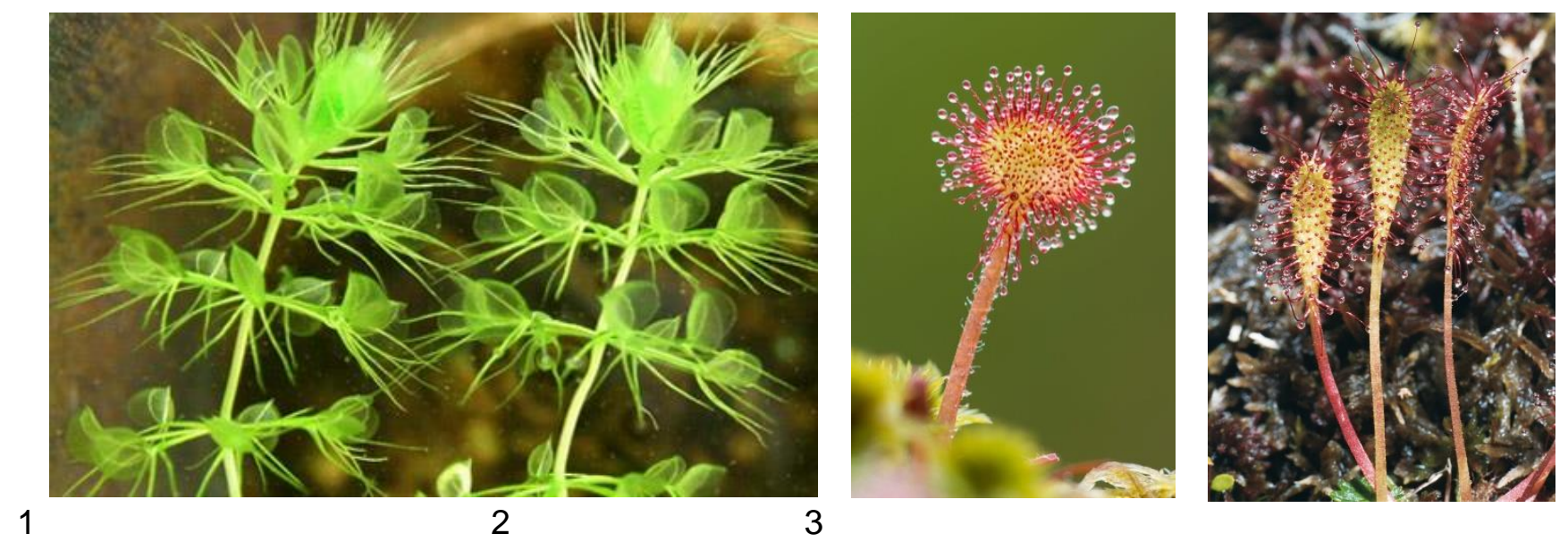

Рис. 6. Альдрованда пузырчатая (1, www.wikipedia.org), росянка круглолистная (2, https://www.wday.ru), росянка английская (3, www.wikipedia.org)

Росянки (рис. 6),произрастающие главным образом на сфрагновых болотах, ловят насекомых с помощью имеющихся листьях железистых волосков, одни из которых вырабатывают клейкий секрет, с помощью которого насекомое и улавливается, другие - пищеварительный фермент.

Семейство Пузырчатковые представлено одним родом пузырчатка (UtriculariaL.). B Приморье произрастают пузырчатки южная (U. australisR.Br.), крупнокорневая (U. macrorhizaLeConte) (рис. 7), средняя (U. intermediaHayne) и малая (U. minorL.). Пузырчатки являются водными растениями (обитают в мелких водоёмах, на болотах) и улавливают добычу путем видоизменённых подводных листьев, части которых превращены в ловчие пузырьки. 

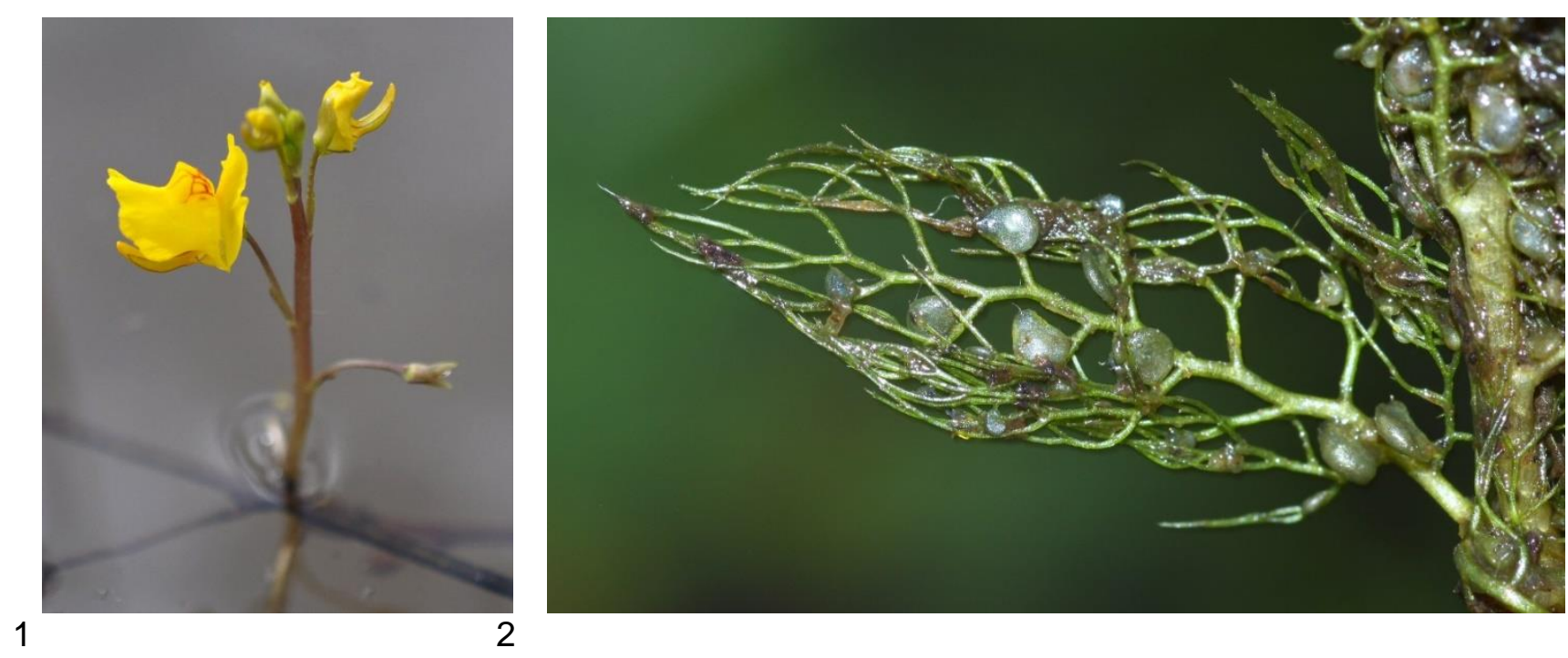

Рис. 7. Пузырчатка крупнокорневая (1) и её ловчие пузырьки (2) (https://www.plantarium.ru)

\section{2. Метаморфозы, служащие для накопления веществ}

Многолетним растениям необходимо иметь определенный запас питательных веществ или воды на случай возникновения стрессовых ситуаций (засуха, сниженный фотосинтез и др.). Накопление веществ может происходить в различных вегетативных органах - листьях, стеблях, в побеге в целом, в почке.

\section{1. Корневище}

Корневище - подземный или ползущий по поверхности почвы побег, выполняющий функции отложения запасов, возобновления и часто вегетативного размножения (Серебряков, Серебрякова, 1965). На корневище имеются чешуевидные листья, почки и придаточные корни. Корневище функционирует в течение нескольких, иногда многих лет, нарастая верхушкой - моноподиально: вороний глаз (Paris), либо симподиально: сныть (Aegopodium), купена (Polyginatum), пырей, (Elytrigia), осока, (Carex). У некоторых видов в первые годы жизни нарастание моноподиальное, а после перехода к цветению - симподиальное: ирис (Iris). Корневища, выполняющие запасающую функцию, обычно утолщены.

Значительное число корневищных высших растений имеется во флоре Приморья (Буч и др., 1981; Сосудистые..., 1985-1996). Прежде всего это растения отделов Хвощевидные (Equisetophyta), Папоротниковидные (Pteridophyta). Корневища отсутствуют у голосеменных растений (Pinophyta), встречаются, хотя и нечасто, у представителей отделов Моховидные (Bryophyta) и Плауновидные (Lycopodiophyta). У цветковых растений (Magnoliophyta) также преобладают корневищные виды.

У растений Приморья можно обнаружить все существующие виды корневищ. Так, например, корневища, служащие преимущественно для накопления питательных веществ, имеются у представителей родов купена (PolygonatumMill.) (рис. 8), башмачок (CypripediumL.), смилацина (SmilacinaDesf.) (рис. 8) и др.

\section{2. Клубень}

Клубень - утолщенная часть стебля, состоящая из одного или нескольких междоузлий. В узлах клубней имеются редуцированные листья или рубцы от них, в их пазухах находятся почки (т.н. глазки). Побеговая природа клубней проявляется в наличии апикального доминирования - терминальный глазок доминирует над остальными. Формирование клубня связано с накоплением крахмала и утратой органом полярности (Игнатьева, Андреева, 2008).

В зависимости от расположения клубни могут быть погруженными в почву (подземные клубни) и представлять собой расширенное основание стеблей (наземные клубни). 

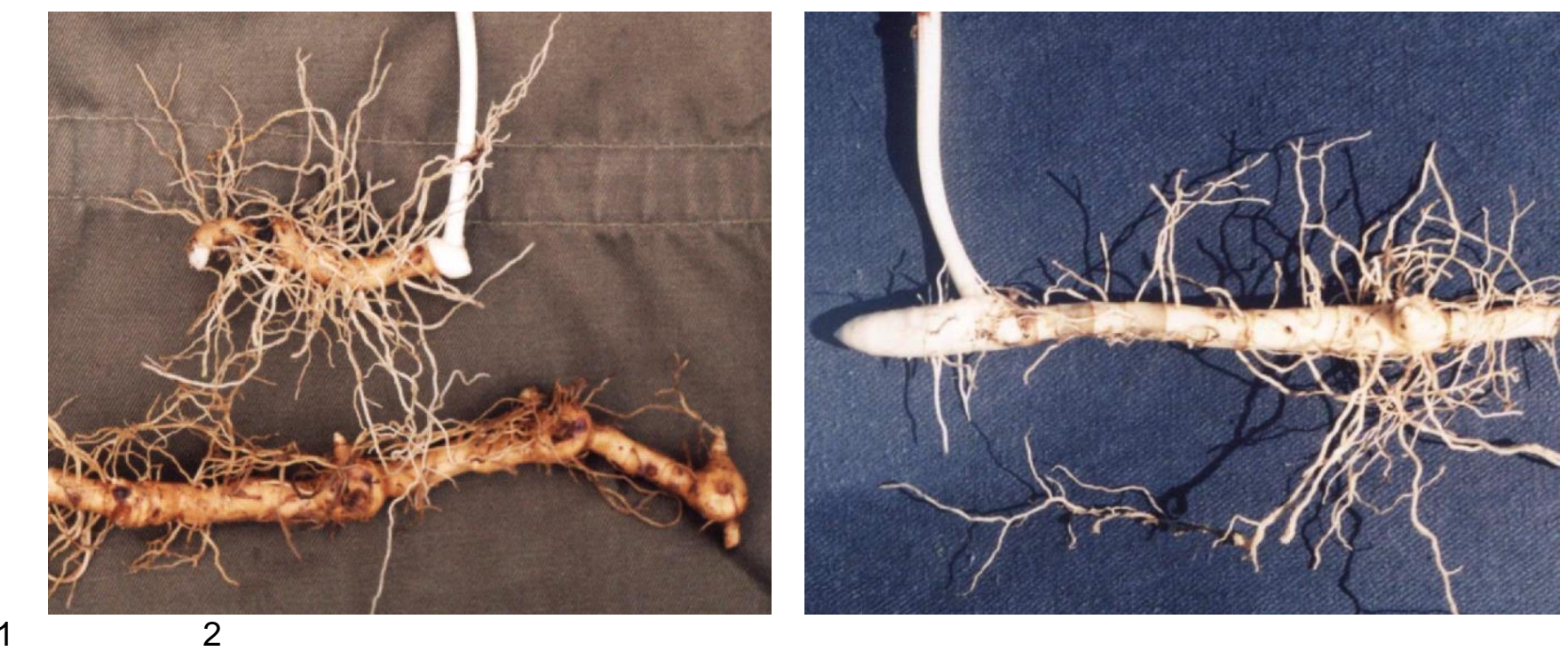

Рис. 8. Корневища с запасающей функцией смилацины волосистой - SmilacinahirtaMaxim. (1) и купены душистой - Polygonatumodoratum (Mill.) Druce (2) (фото В. Рыбаковой)

Подземные клубни

Подземные клубни могут возникать на особых подземных видоизмененных побегах, столонах, и представлять собой утолщение его верхушечной почки. Такие клубни существуют лишь от одного вегетационного периода до другого, полностью отмирая после расходования накопленных веществ.

Семейство Частуховые - AlismataceaeVent.

Стрелолист трёхраздельный (SagittariatrifoliaL.) и стрелолист плавающий (S. natansPall.) корневищные растения, образующие (обычно к осени) столоны, заканчивающиеся клубнями (рис. 9). В клубнях довольно много крахмала, поэтому растения используются в пищевых целях.
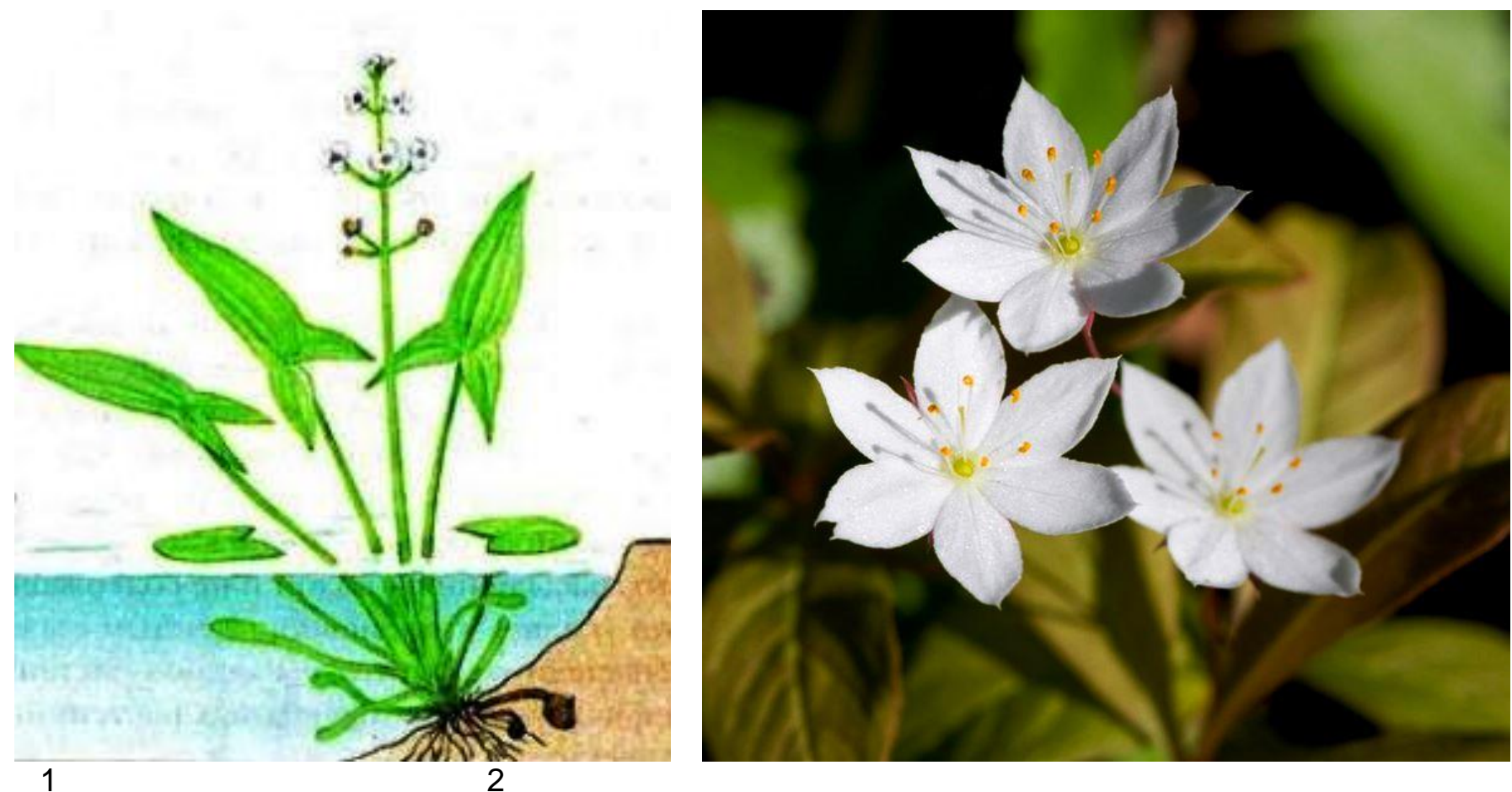

Рис. 9. Стрелолист трёхраздельный (1, www.wikipedia.org), седмичник европейский (2, www.prosad.ru) 
Клубни столонного происхождения имеются у седмичника европейского (TrientaliseuropaeaL.) из семейства Первоцветовые (PrimulaceaeVent.) (рис. 9). Столоны седмичника довольно длинные, тонкие, беловатые. Очень тонкие, нитевидные (до 1 мм в диаметре) столоны к концу лета развиваются у двух видов двулепестника из семейства Кипрейные (OnagraceaeJuss.) - альпийского (CircaeaalpinaL.) (C. caulescens (Kom.)Hara).

Клубни могут быть результатом утолщения корневища или его участков. Как и столонные клубни, они существуют лишь один год.

Семейство Барбарисовые - BerberidaceaeJuss.

Стеблелистмощный - CaulophyllumrobustumMaxim.Это растение имеет мощное, клубневидно разрастающееся корневище, узловатое, с немногочисленными корнями.

Семейство Сытевые - CуреraceaeJuss.

У растений рода клубнекамыш (Bolboschoenus (Aschers.)Palla) - клубнекамыша Ягара (B. yagara (Ohwi) A.E. Kozhevnikov), Десулави (B. desoulavii (Drob.)A.E. Kozhevnikov), Кожевникова (B. kozhevnikovii (Litv.)A.E. Kozhevnikov) имеются клубневидно утолщенные корневища 1-3 см в диаметре.

Семейство Бобовые - FabaceaeLindl. s.l.

Произрастающая на юге Приморья пуерария лопастная (Puerarialobata (Willd.)Ohwi) имеет мощные горизонтально расположенные клубневидные корневища (рис. 10).
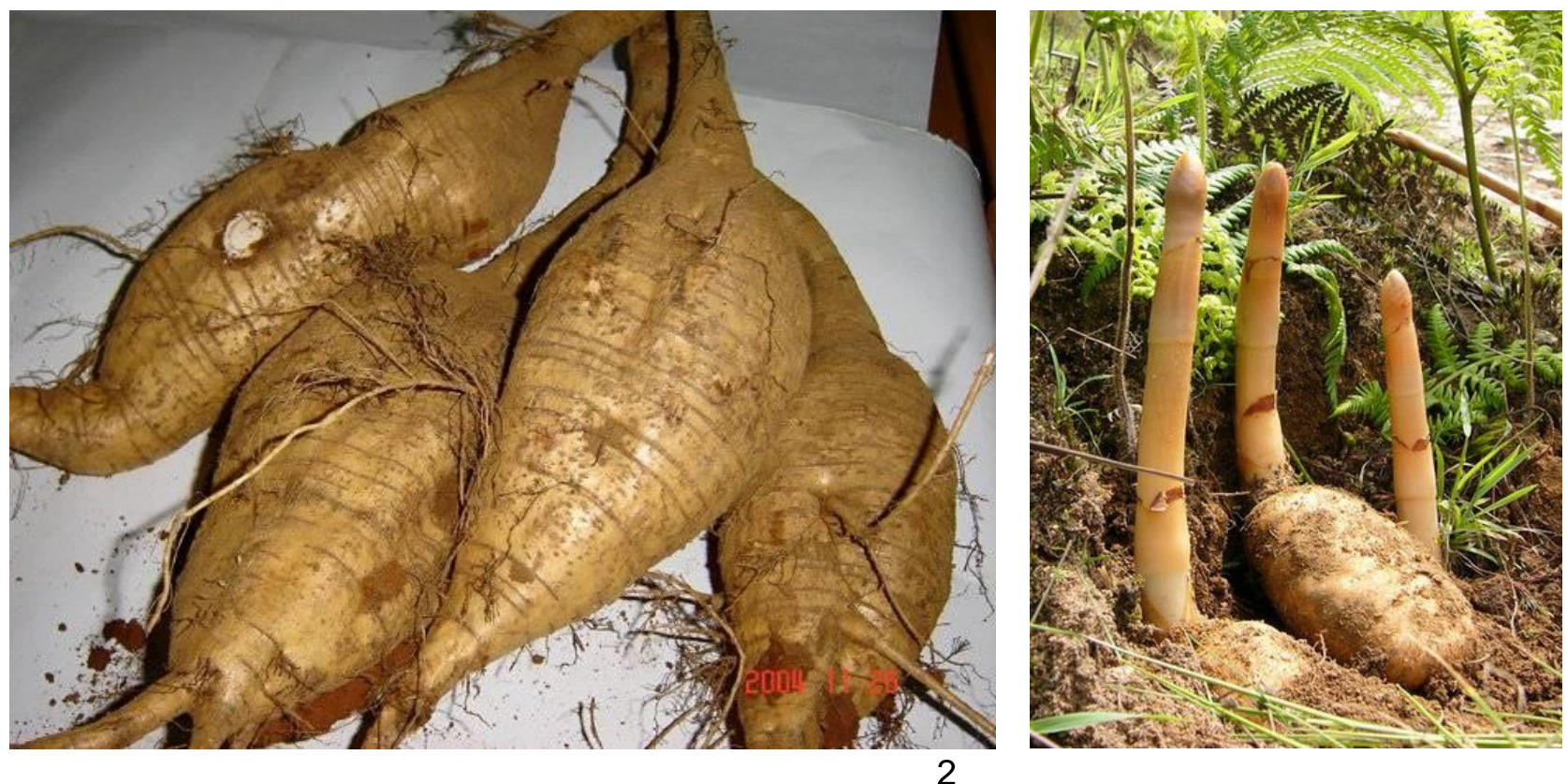

Рис. 10. Корневища пуерарии лопастной (1, https://www.greeninfo.ru) и пузатки высокой (2, https://golesosad.com)

Семейство Орхидные - OrchidaceaeJuss.

Пузатка высокая (GastrodiaelataBlume) имеет клубневидно утолщенное корневище (рис. 10).

Семейство Яснотковые, Губоцветные - LamiaceaeLindl.

Четкообразно утолщенные корневища имеются у шлемника четковиднокорневищного (ScutellariamoniliorrhizaKom.).

Клубни могут возникать в базальной части главной оси. В этом случае в их формировании принимают участие главным образом гипокотиль, а также и более верхние междоузлия, особенно эпикотиль. В отличие от предыдущих типов, эти клубни всегда ортотропны и являются многолетними.

Семейство Лютиковые - RanunculaceaeJuss.

Весенник звёздчатый - EranthisstellataMaxim. У этого растения клубень шаровидный 
(рис. 11), 0,5-2 см в диаметре, от него отходят придаточные корни.

Семейство Маковые - PapaveraceaeJuss.

Из растений этого семейства клубнем гипокотильного происхождения обладают многие виды рода хохлатка (CorydalisVent.). Клубень овальный или шаровидный (рис. 11), в среднем около 1-1,5 см в диаметре.

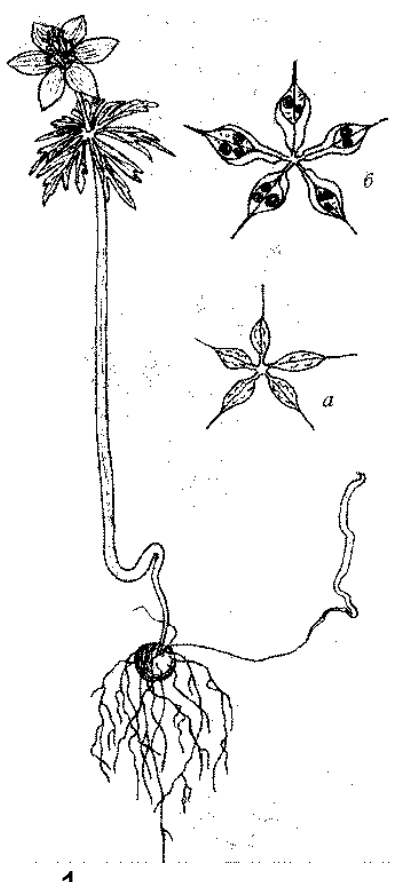

1

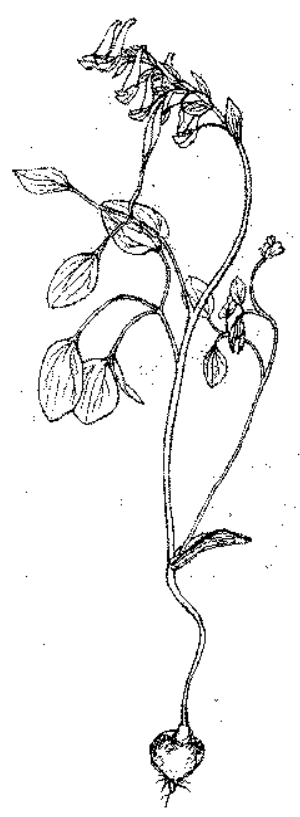

2

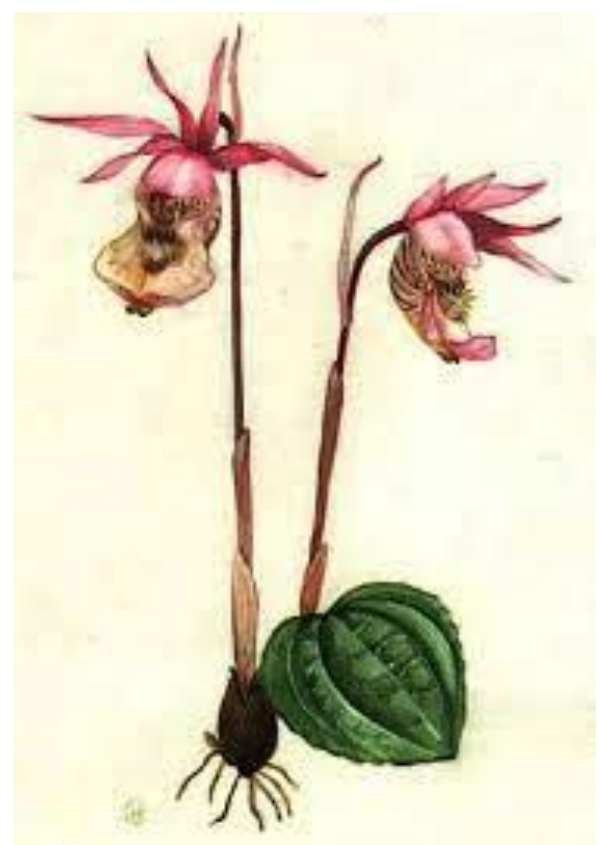

Рис. 11. Гипокотильные клубни весенника звёздчатого (1, Фролов, Коляда, 2000), Хохлатки ползучей (CorydalisrepensMandletMuehl.) (2, Фролов, Коляда, 2000), наземный клубень калипсо луковичной (3, www.wikipedia.org)

Семейство Ароидные - AraceaeJuss.

Однопокровница амурская (аризема амурская) - ArisaemaamurensisMaxim. Растение имеет довольно крупный клубень до 6-7 см в диаметре.

Наконец, весьма оригинальными подземными клубнями обладает сердечник трехнадрезанный (Cardaminetrifida (Lam.exPoir.)B.M. Jones) из семейства Капустовые (BrassicaceaeBurnett). Являясь видоизменениями листьев, они имеют вид мелких беловатых плоских клубней до 0,8 см длины и 0,6 см ширины, на верхушке трёхзубчатых (Беркутенко, 1988). На корневище они располагаются на тонких нитевидных черешках.

Наземные клубни

У некоторых растений клубневидно разрастается основание стебля. Из растений Приморского края это предствителисемейства Орхидные (OrchidaceaeJuss.).

Род Калипсо -CalypsoSalisb.

B Приморье произрастает калипсо луковичная (C. bulbosa (L.)Oakes) - она имеет надземное клубневидное образование с перепончатыми влагалищами и шнуровидными мочками корней (рис. 11).

Род Мякотница - MalaxisSoland. exSw.

Наземный клубень мякотницы однолистной (M. monophyllos (L.)Sw.) яйцевидный, окружен влагалищами отмерших листьев.

\section{3. Луковица}

Луковица представляет собой укороченный видоизмененный побег, состоящий из редуцированного стебля (донца), который несет многочисленные тесно расположенные чешуевидные мясистые листья (Баранова, 1971). Для луковицы характерны, как и для побега, пазушные и верхушечные почки, дающие надземные побеги.От донца отходят придаточные 
корни (в т.ч.контрактильные). Снаружи луковица покрыта сухими пленчатыми чешуями, выполняющими защитную функцию.

По типу строения и расположения чешуй различают три типа луковиц: а) туникатные (концентрические): каждая чешуя такой луковицы, срастаясь краями, полностью охватывает внутренние, в результате чего создается впечатление, будто чешуи вложены друг в друга. Характерны для видов рябчика (Fritillaria), лука (Allium); б) полутуникатные: чешуи не срастаются краями и охватывают наполовину или более расположенные внутри чешуи. Свойственны пролеске (Scilla); в) черепитчатые: чешуи накладываются друг на друга и охватывают менее половины расположенных внутри чешуй. Характерны для лилий (Lilium).

Из растений Приморского края луковица свойственна представителям семейств Лилиевые (Врищ, 1972) и Луковые.

Семейство Лилиевые (LiliaceaeJuss.) (Баркалов, 1987).

Род Лилия (LiliumL.). Для растений рода характерны черепитчатые луковицы.

Лилия пенсильванская, лилия даурская - L. pensylvanicumKer-Gawl. Луковица белая, шаровидная (рис. 12), 2-7 см ширины, легко распадающаяся. Чешуи многочисленные, мясистые, выпуклые, ланцетные, у старых луковиц с перетяжкой примерно посередине.

Лилия Буша, лилия красивенькая - L. buschianumLodd. Луковица белая, яйцевидная, 3,5 см длины, компактная. Чешуи немногочисленные, суховатые, крупные, яйцевидноланцетные, плотные.
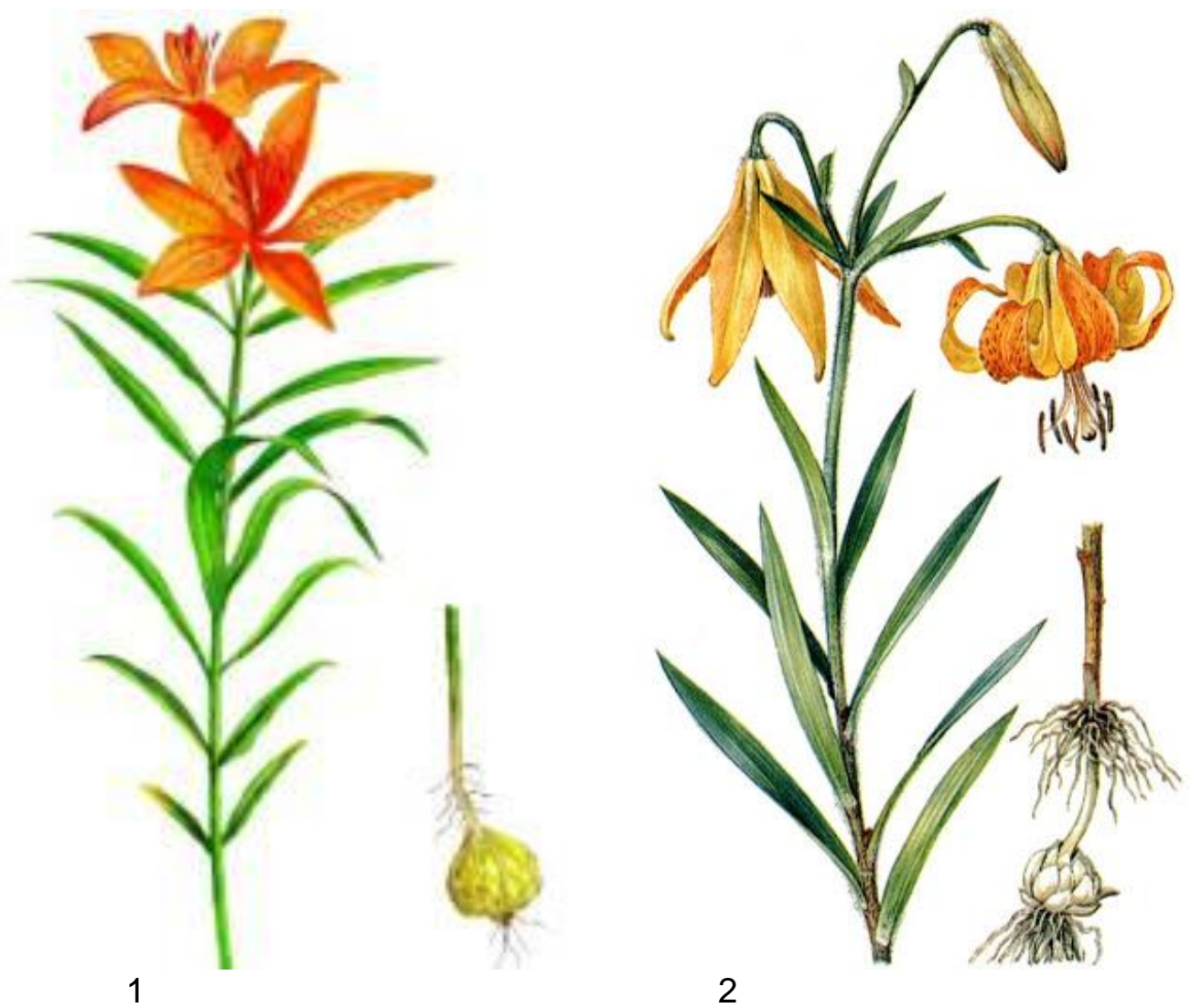

Рис. 12. Лилия пенсильванская (1, https://cicon.ru), лилия ланцетолистная (2, www.wikipedia.org)

Лилия ланцетолистная, лилия тигровая - L. lancifoliumThunb. Луковица белая, широкояйцевидная (рис. 12), 4-7 см длины и 5-8 см ширины. Чешуи широкояйцевидные, коротко заострённые, плотные, мясистые.

Лилия ложнотигровая - L. pseudotigrinumCarr. Луковица белая, шаровидная, плотная, 4 см длины и 4 см ширины. Нередко имеется длинный подземный стебель, на котором развиваются 1-5 дочерних луковиц. Чешуи немногочисленные, яйцевидные, выпуклые, острые, 1,5-2 см длины и 1,3-1,6 см ширины. 
Лилия поникающая - L. cernuumKom. Луковица белая, узкояйцевидная или яйцевидная, плотная, 3-6 см длины. Чешуи немногочисленные, мясистые, яйцевидные, с заострёнными верхушками.

Лилия карликовая - L. pumilumDC. Луковица белая, узкояйцевидная, плотная, 2,5-5 см длины. Чешуи немногочисленные, яйцевидные, на верхушке заострённые.

Лилия мозолистая - L. callosumSieb. etZucc. Луковица белая, широкояйцевидная, 22,5 см длины. Чешуи немногочисленные, ланцетные или яйцевидные, на верхушке острые.

Лилия двурядная - L. dictichumNakai. Луковица белая, яйцевидная или широкояйцевидная, рыхлая, 2-3 $(4,5)$ см длины и 4 см ширины, черепитчатая. С внешней стороны имеются 4-7 усохших чешуй - плёнчатых, сероватых, прозрачных. Донце конусовидное. От него отходят придаточные корни до 8-10 см длины. Часть из них контрактильные. Чешуи многочисленные (до 100), белые, голые, блестящие в общем очертании ланцетные, острые или притупленные, по краю иногда пильчатые, Часто чешуи дважды, трижды сочленённые, но встречаются и цельные чешуи - до 2 см длины и 0,8 см ширины. Членистые чешуи имеют размеры: дважды членистые - первый членик 1,5 см длины и 0,7 см ширины у основания, второй членик - 1 см длины и 0,6 см ширины у основания; трижды членистые - первый членик 1,3 см длины и 0,8(1) см ширины, второй членик 1 см длины и 0,8 см ширины, третий 0,7 см длины и 0,6 см ширины. На поперечном срезе заметно, что клетки чешуй плотно заполнены крахмальными зернами.

Род Гусиный лук (GageaSalisb.).

У представителей рода луковицы неправильно яйцевидные, до 1-2 см длины, с тёмнокоричневыми (гусиный лук гиенский - G. hiensisPasch.)или буровато-серыми (гусиный лук Накаи - G. nakaianaKitag.) оболочками, в основании с несколькими луковичками.
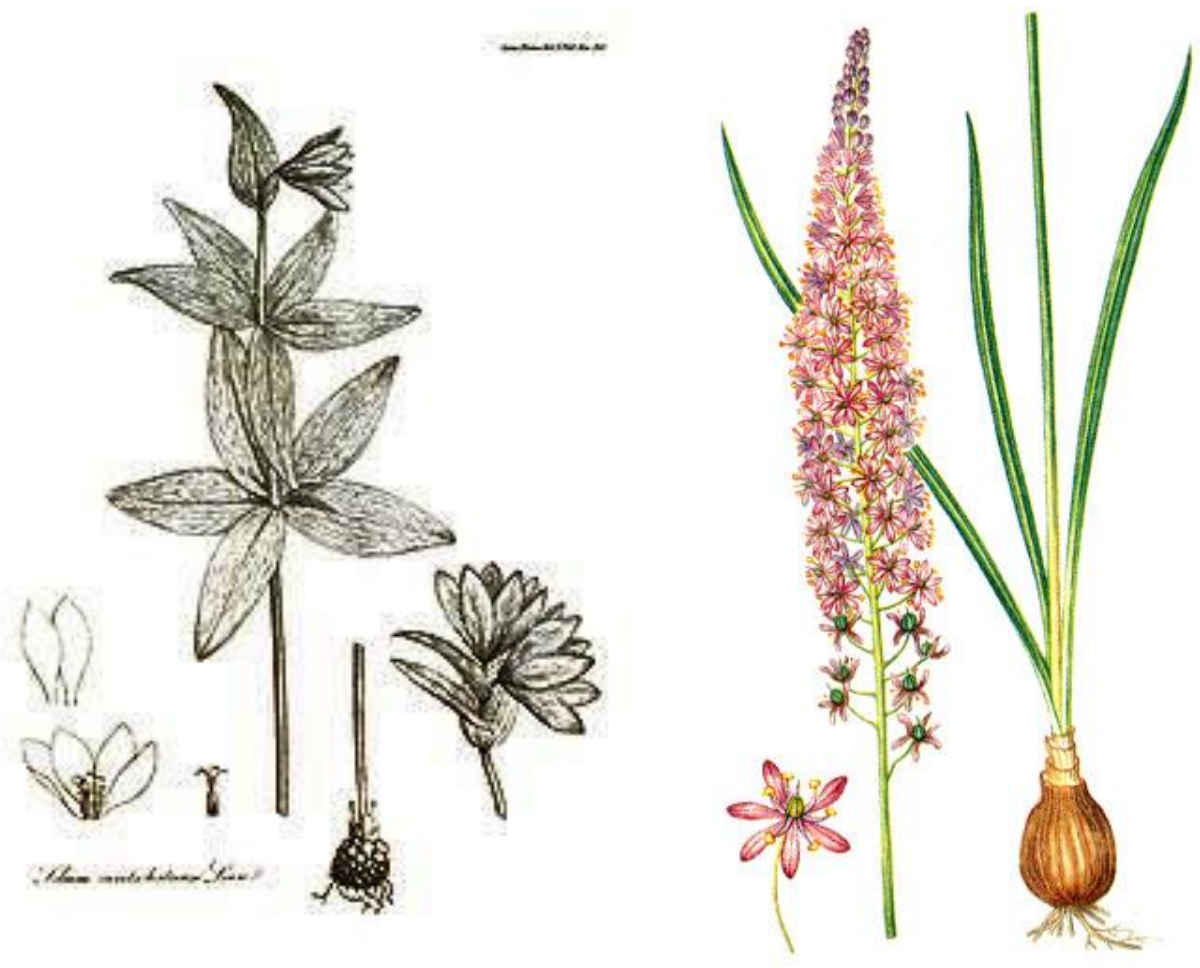

1

2

Рис. 13. Рябчик камчатский (1, https://cicon.ru), пролеска пролесковидная (2, www.wikipedia.org)

Род Рябчик (FritillariaL.).

Луковицы округлые (рис. 13), до 1,5(3) см в диаметре, у рябчика уссурийского (F. ussuriensisMaxim.) с цельными чешуями, у рябчиков камчатского (F.camschatcensis (L.)Ker-Gawl.) и Максимовича (F. maximowicziiFreyn) из более или менее многочисленных луковичек. 
Род Ллойдия (LloydiaReichenb.).

В Приморском крае произрастают два вида - ллойдия поздняя (L. serotina (L.) reichenb.) с узкими, продолговато-яйцевидными луковицами, покрытыми сероватыми растрескивающимися оболочками, и ллойдиятрёхцветковая (L. triflora (Ledeb.)Baker) с небольшими округлыми луковицами, покрытыми буроватыми цельными оболочками.

Род Пролеска (ScillaL.).

Единственный представитель рода, произрастающий в южной части Приморья, пролеска пролесковидная (S. scilloides (Lindl.)Druce), имеет яйцевидные луковицы (рис. 13) до 4 см длины и 2,5 см ширины, покрытые сизовато-бурыми цельными оболочками.

Семейство Луковые (AlliaceaeJ.Agardh) (Баркалов, 1987).

Род Лук (AlliumL.). В Приморском крае произрастают 19 видов лука, имеющие как одиночные (шаровидные или яйцевидные) луковицы, так луковицы, располагающиеся по нескольку (2-4) на более или менее коротком корневище.

\section{4. Клубнелуковица}

Переходная форма между типичным клубнем и луковицей. Листовые чешуи клубнелуковицы сухие, а запасные вещества откладываются в стеблевой части. На оси клубнелуковицы хорошо заметны узлы и междоузлия. Клубнелуковицы характерны для таких растений, как гладиолус (Gladiolus), шафрран (Crocus), безвременник (Colchicum), представителей семейств Ирисовые (Iridaceae), Амариллисовые (Amarillidaceae).

Из растений Приморья клубнелуковицей обладает ореорхис раскидистый (Oreorchispatens (Lindl.)Lindl.из семейства Орхидные, Orchidaceae) (Ракова, 1990).

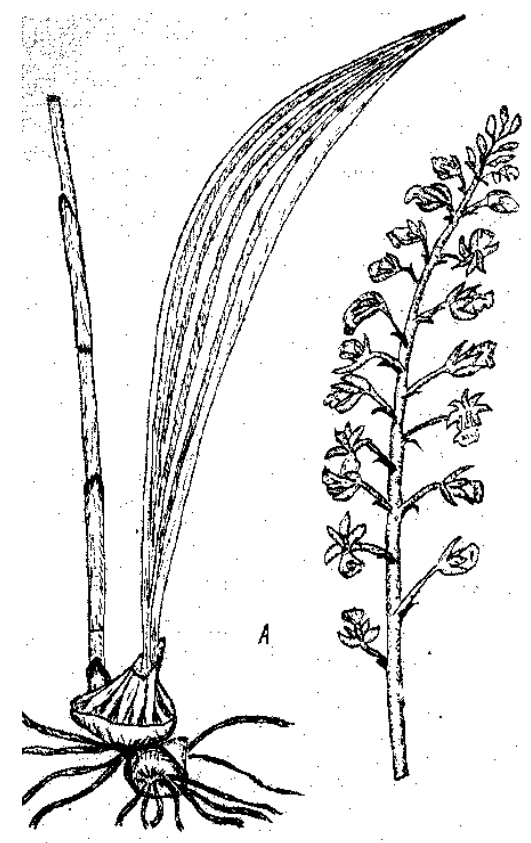

Рис. 14. Ореорхис раскидистый (Ракова, 1990)

Взрослое растение насчитывает от 1 до 5 плотно прилегающих друг к другу клубнелуковиц (рис. 14). Верхняя часть их покрыта основанием чешуевидного листа. Постепенно в каждой клубнелуковице образуется три зоны, выполняющие различные функции.У каждой сфрормированной клубнелуковицы образуется до 5 придаточных корней длиной около 5$6 \mathrm{~cm}$. Их молодые окончания белые, с корневыми волосками. Старая часть корней бурая, часто покрыта переплетенными гифами гриба. Придаточные корни равномерно утолщённые, в диаметре составляют 2,5-3 мм. Для них свойственен слабый геотропизм - они направлены в разные стороны, иногда даже вверх.

\section{3. Метаморфозы, обеспечивающие прикрепление к поре}

\section{1. Усики}

Усики представляют собой видоизменённые побеги, листья либо прилистники. Они свойственны лиановым и лазящим растениям и выполняют функцию прикрепления стебля к 
опоре. Стебель таких растений обычно не способен принимать вертикальное положение вследствие слабого развития механической ткани.

Усики побегового происхождения

Встречаются у представителей семейств Тыквовые и Виноградовые. Усики растений, входящих в эти семейства, различаются происхождением, размерами, формой.

Семейство Тыквовые - CucurbitaceaeJuss.

Представители тыквовых имеют усики, являющиеся видоизменением побега. Это тладианта сомнительная (ThladianthadubiaBunge) (рис. 15), схизопепонбриониелистный (SchizopeponbryoniifoliusMaxim.), актиностемма лопастная (Actinostemmalobatum (Maxim.)Maxim. exFranch. etSavat.), эхиноцистис лопастный, или «стреляющий плющ» (Echinocystislobata (Michx.)Torr.etGray).

Последнее растение, родом из Северной Америки, было занесено в Европу и затем широко распространилось в Евразии. Его тонкие слабые побеги поддерживаются на опоре с помощью крепких ветвящихся 3-4-раздельных усиков, закрученных в крутую сильную спираль (рис. 15), похожую на часовую пружину.

Семейство Виноградовые - VitaceaeJuss.

Для растений этого семейства характерны усики, представляющие собой видоизмененные соцветия. Располагаются они в узлах супротивно листьям.
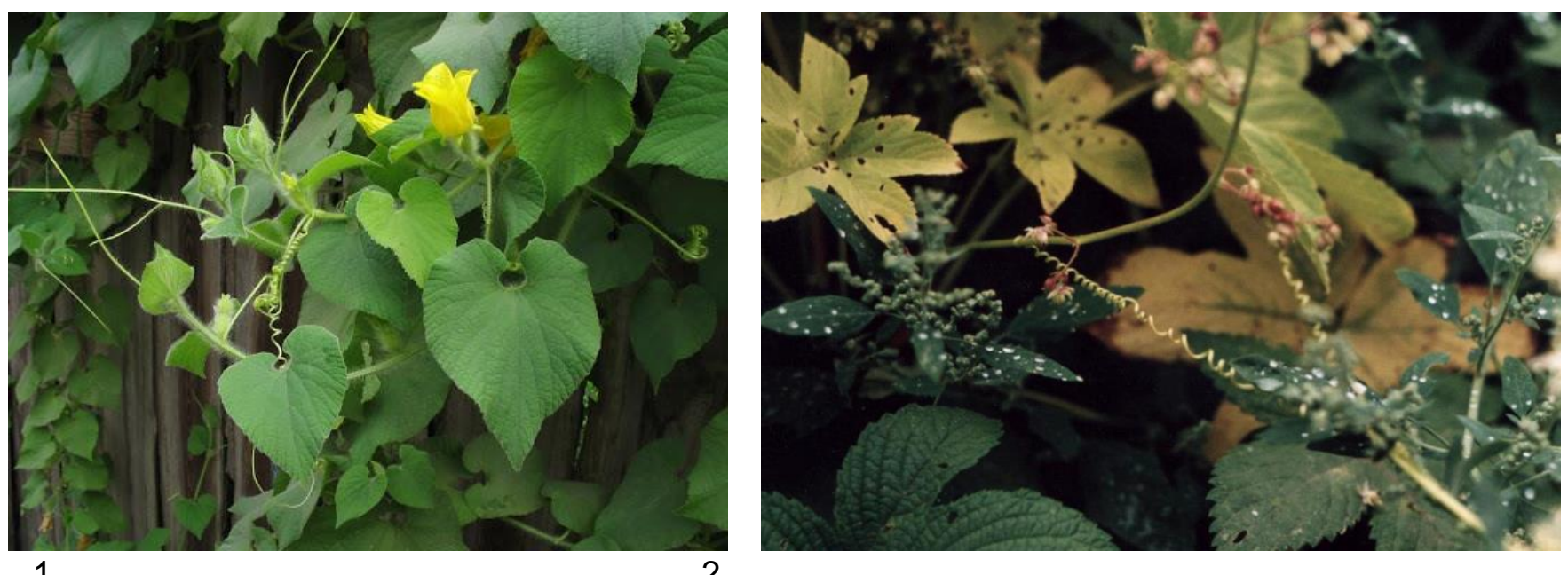

Рис. 15. Усики тладианты сомнительной (1, www.wikipedia.org), эхиноцистиса лопастного (2, фото В. Рыбаковой)

Род Виноград - VitisL. (рис. 16)

Виноград амурский - V. amurensisRupr. Усики растения до 30 см длины и 0,3 см в диаметре, зелёные (однако на свету приобретают красноватую окраску), голые или опушённые удлинёнными белыми закручивающимися волосками. Усики обычно разветвляются на две оси, одна из них(морфологически нижняя) длиннее верхней. Они обвивают опору спирально как по часовой стрелке, так и против. При этом нередко бывает так, что одна часть усика обвивает опору почасовой стрелке, другая часть того же усика - против; направление обвивания может меняться. Нижняя часть усика часто сворачивается в спираль, обеспечивая эластичное соединение с опорой, необходимые изгибы и повороты стебля при росте, предотвращает механические повреждения стебля, а усики - от разрыва. Анатомическое строение усика свидетельствует о его побеговом происхождении. Под эпидермой располагается кора, в которой находятся крупные участки уголковой колленхимы. Они примыкают к граням стебля (в поперечном сечении он является 6-гранным). Центральный цилиндр ярко выражен, проводящие пучки образуют кольцо, над каждым пучком находится участок склеренхимы. 

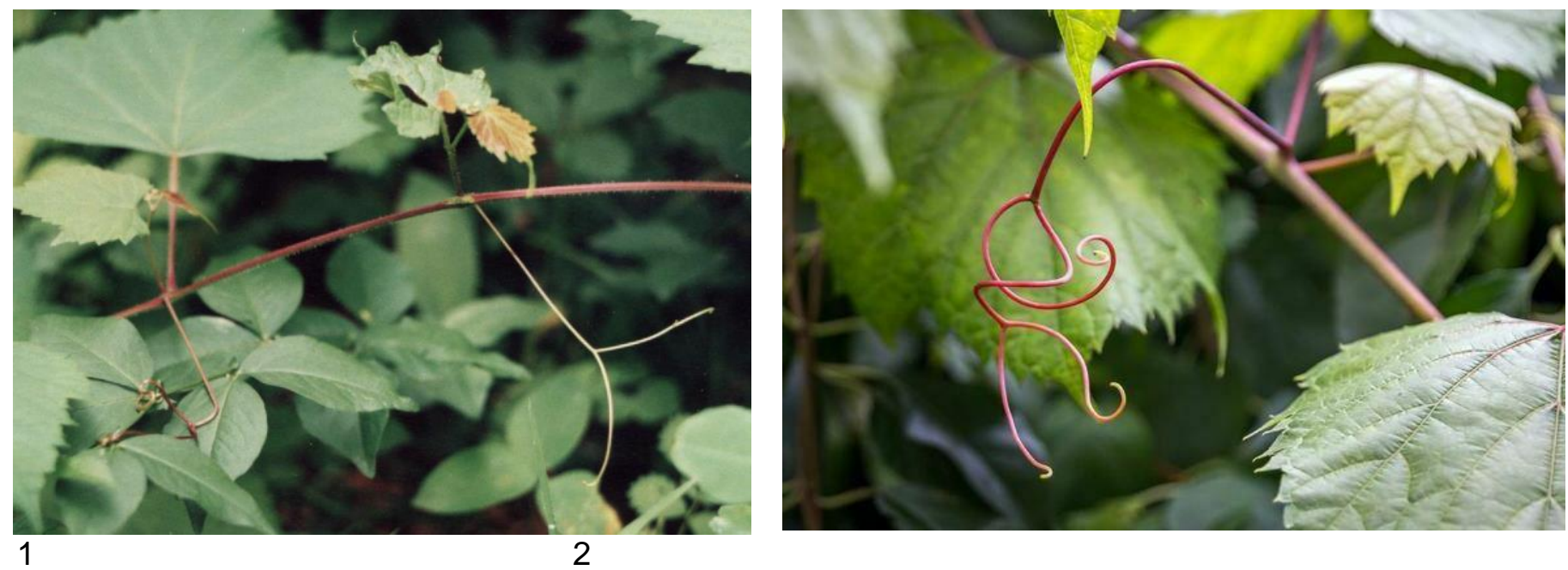

Рис. 16. Усики виноградовника короткоцветоножкового (1, фото А. Коляды), винограда (2, https://ogorodnash.ru)

Род Виноградовник - AmpelopsisMichx.

Виноградовник короткоцветоножковый - A. brevipedunculata (Maxim.) Trautv. Усики относительно короткие (до 10 см длины) (рис. 16).

Виноградовник разнолистный - A. heterophylla (Thunb.) SieboldetZucc. Усики до 7-10 см длины и 0,1 см в диаметре, зеленые или красноватые (на свету).

Виноградовник японский - A. japonica (Thunb.) Makino. Усики 10-12 см длины, тонкие, до 0,9 см в диаметре, голые.

Род Девичий виноград - ParthenocissusPlanch.

Девичий виноград триостренный - P. tricuspidata (SieboldetZucc.) Planch. Усики короткие, 3-4 см длины, разветвлённые. На концах усиков имеются дисковидные расширения, выделяющие клейкое вещество, с помощью которого и происходит прикрепление к опоре.

Усики листового происхождения

Имеются у растений семейства Бобовые (FabaceaeLindl. s.I.). У бобовых в усик видоизменяются части листа или весь лист (Яковлев, 1991). На примере гороха было выявлено, что если размер меристематического бугорка превышает некий верхний предел, то он превращается в участок рахиса, если нет - образуется усик; при промежуточных значениях образуется листочек.В усик может видоизмениться и весь лист - это наблюдается у некоторых видов чины (Lathyrusaphaca), в этом случае роль фотосинтеза выполняют крупные прилистники.

Из бобовых, произрастающих в Приморье, усиками обладают представители родов горошек (ViciaL.): японский (V. japonicaA.Gray), Ворошилова (V. woroschiloviN.S.Pavlova), приятный (V. amoenaFisch.) (рис. 17), амурский (V. amurensisOett), мышиный (V. craccaL.), мохнатый ( $V$. villosaRoth), заборный ( $V$. sepium), сорно-полевой ( $V$. segetalisThuill.), волосистый (V. hirsuta (L.) S.F. Gray); чина (LathyrusL.): Давида (L. davidiiHance), японская (L. јaponicusWilld.) (рис. 17), низкая (L. humilis (Ser.)Spreng.), волосистая (L. pilosusCham.), пятижилковая (L. quinquenervius (Miq.)Litv.), луговая (L. pratensisL.), клубневая (L. tuberosusL.).

Усики этих растений представляют собой верхние части листьев, цепляющиеся за опору, обвивая ее. При этом, укрепляясь как на опоре, так и на собственных соседних стеблях и листьях, растения создают довольно прочную рыхлую, хорошо аэрируемую структуру, которая максимально отвечает требованиям фотосинтеза. 

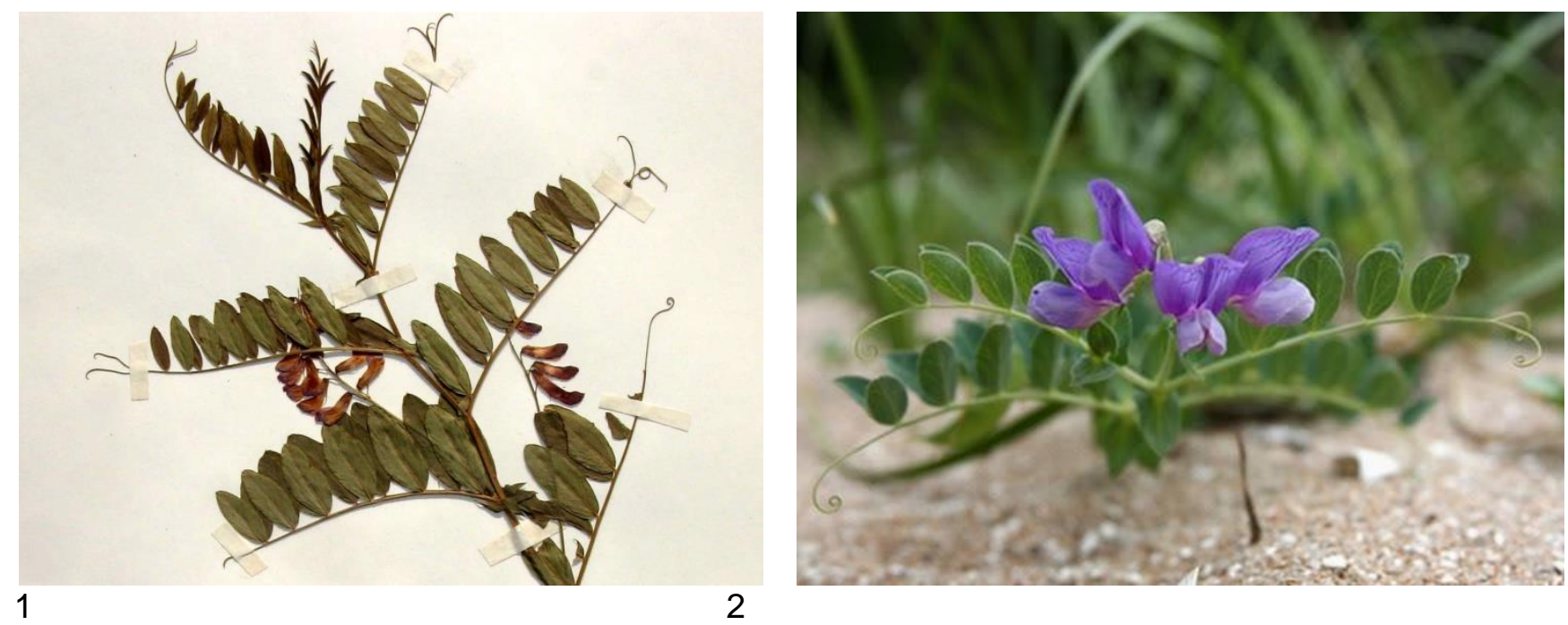

2

Рис. 17. Горошек приятный (1, http://bogard.isu.ru), чина японская (2, www.wikipedia.org)

Семейство Сассапарилевые - SmilacaceaeVent.

Усики прилистникового происхождения

Единственный представитель этого семейства (род Сассапариль - SmilaxL.), произрастающий в Приморском крае - сассапариль Максимовича (S. maximowiczikoidz.). Усики этого лазающего кустарника, произрастающего по долинным лесам, в зарослях кустарников располагаются в основании черешков, супротивные (рис. 18), чаще всего закручиваются около этого же или соседнего узла, 8-9 см длины и около 0,8 мм в диаметре.

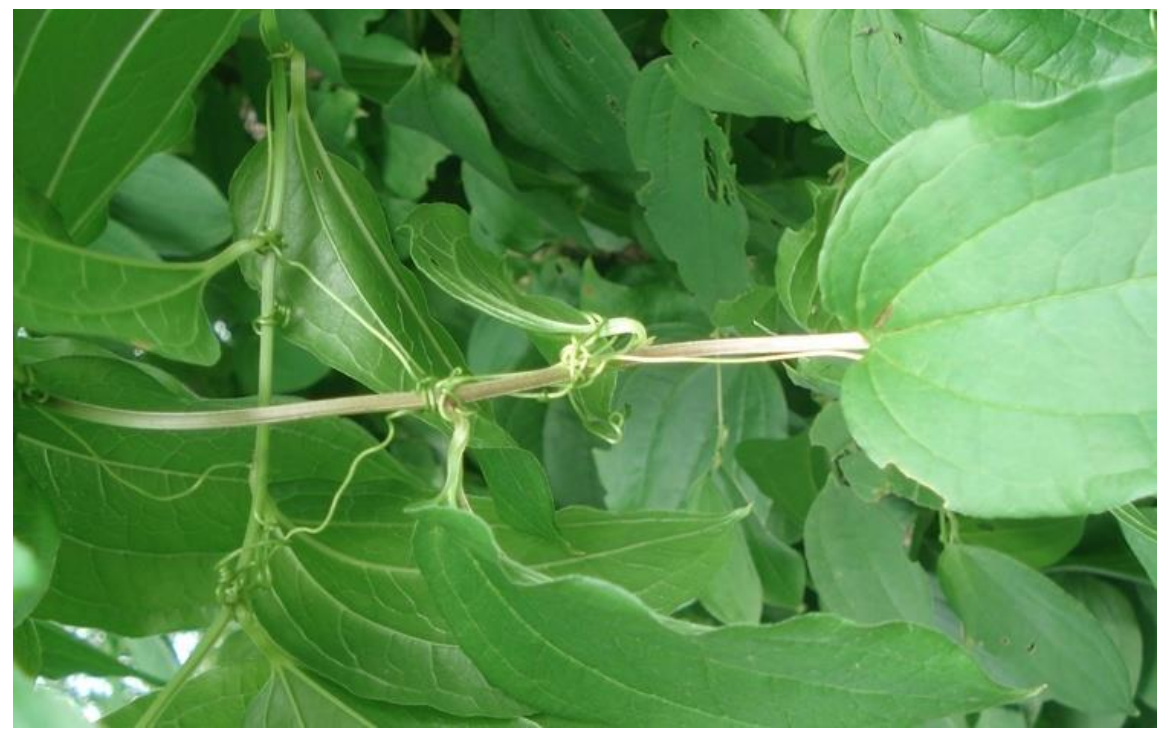

Рис. 18. Усики сассапарили Максимовича (фото А. Коляды)

\section{4. Колючки}

Семейство Древогубцевые - CelastraceaeLindl.

Род Древогубец - Celastrus L.

Древогубецплетеобразный - C. flagellarisRupr.

Колючки древогубцаплетеобразногоявляются видоизмененными наружными почечными чешуями.Они парные, жёсткие, острые, изогнуты книзу (рис. 19), расширенные к основанию. Колючки вонзаются в кору деревьев, благодаря чему могут взбираться по стволу вертикально вверх. С возрастом колючки исчезают (уже у трёхлетних стеблей они не наблюдаются). 


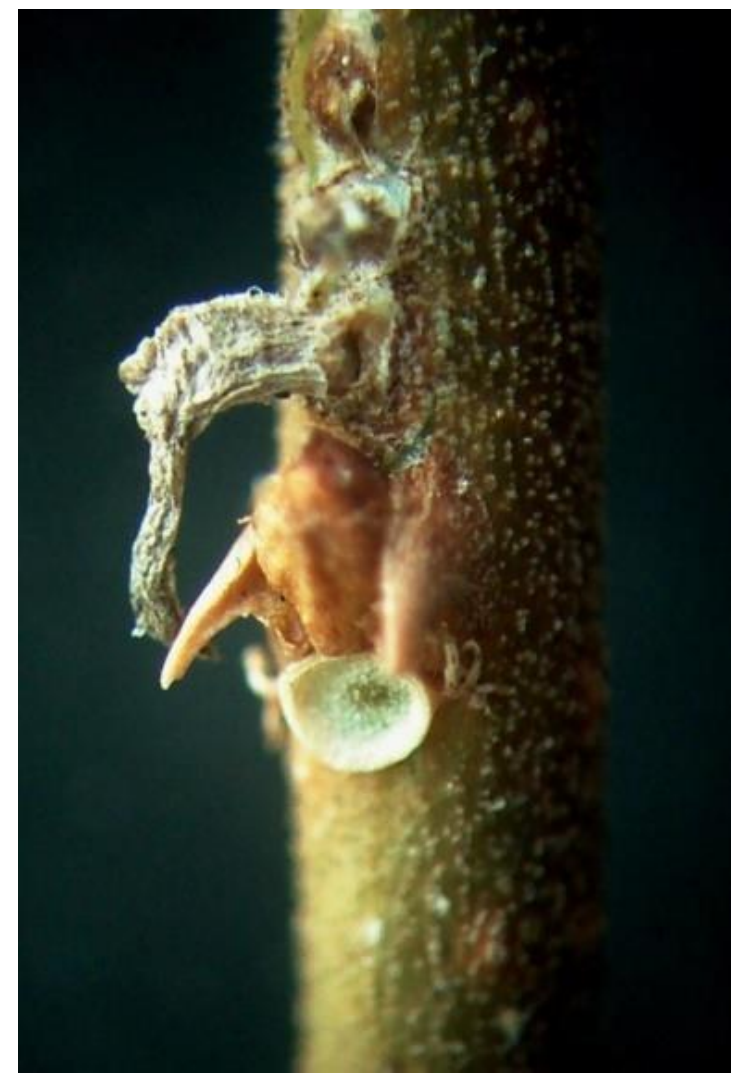

Рис. 19. Узел побега древогубцаплетеобразного (фото А. Коляды)

\section{4. Метаморфозы, служащие для завоевания новой территории и вегетативного размножения}

Некоторые из упомянутых выше видоизменений побега (главным образом подземных) могут принимать участие и в вегетативном размножении (Шалыт, 1960; Коляда А., Коляда Н., 2011). Это корневища, клубни, луковицы, клубнелуковицы.

Корневища, служащие главным образом для вегетативного размножения, не накапливают питательных веществ, они достаточно тонкие, могут распространяться от материнского растений на несколько метров.

Такие корневища имеются у видов рода хлорант (ChloranthusjaponicusSiebold) из одноимённого семейства (ChloranthaceaeR.Br. exLindl.), повой (CalystegiaR.Br.) из семейства Вьюнковые (ConvolvulaceaeJuss.), таких злаков (РоaceaeBarnh.), как пырей (ElytrigiaDesv.)и многих других растений.

Среди специализированных видоизменений побега, служащих для вегетативного размножения и завоевания новой территории можно назвать надземные столоны (Коровкин, 2013).

Они представляют собой недолговечные стелющиеся побеги с удлиненными междоузлиями. Кроме того, они несут листья и осуществляют функцию фотосинтеза. Надземные столоны свойственны довольно большому числу растений (часто видовым эпитетом для них служит слово «ползучий») из различных семейств.

Надземные столоны представлены плетьми и усами. Плети - это столоны, несущие обычные ассимилирующие листья. Концы плетей, укореняясь, образуют подземную часть с укороченным стеблем (розетку), из которой возникают новые плети. С отмиранием междоузлий розетки становятся самостоятельными растениями.

Надземные столоны в виде плетей и усов имеются у целого ряда растений Приморья.

Плетевидные побеги встречаются у растений семейства Яснотковые, или Губоцветные (LamiaceaeLindl.): михениикрапиволистной (Meechaniaurticifolia (Miq.)Makino), будры плющевидной (GlechomahederaceaeL.) (рис. 20), будры длиннотрубчатой (G.Longituba (Nakai) 
Kuprian.), растений рода зюзник (LycopusL.). Плети образует и сердечник лировидный (CardaminelyrataBunge, сем.Капустовые, BrassicaceaeBurnett).

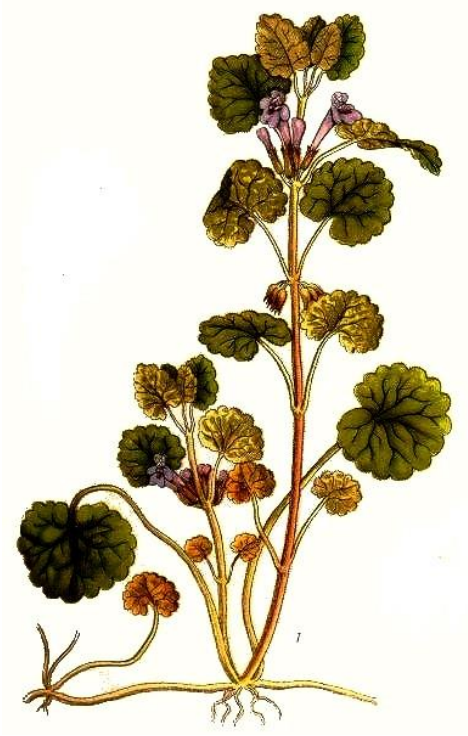

Рис. 20. Будра плющевидная (www.wikipedia.org)

Более специализированные столоны, обычно лишенные листьев, с очень длинными междоузлиями, называют усами. Наиболее ярко усы выражены у земляники восточной (FragariaorientalisLosinsk.) (рис. 21).
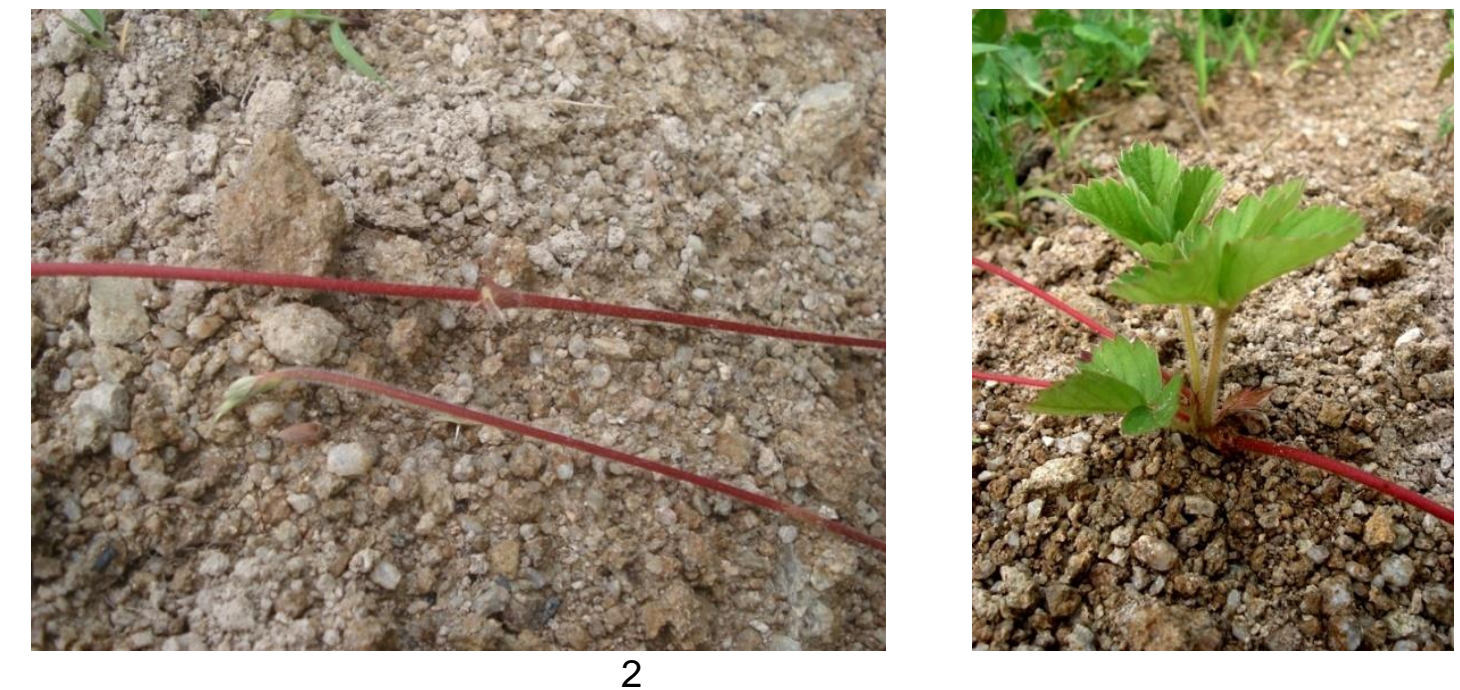

1

Рис. 21. Усы земляники (1), сформировавшееся дочернее растение, давшее, в свою очередь, новые усы (2) фоото А. Коляды)

Они состоят обычно из двух междоузлий до 30 см длины, красноватых, опушённых короткими волосками. У одного растения земляники может фрормироваться несколько усов (рис. 22).

\section{5. Метаморфозы с защитной функцией}

\section{1. Почечные чешуи}

Почечные чешуи представляют собой видоизменённые листья, прилистники или черешки листьев (Фёдоров и др., 1962), защищающие почку от повреждений. Свойственны древесным растениям. Почечные чешуи растений разных видов различаются своими размерами, фрормой, интенсивностью опушения, окраской и др. (рис. 23). 


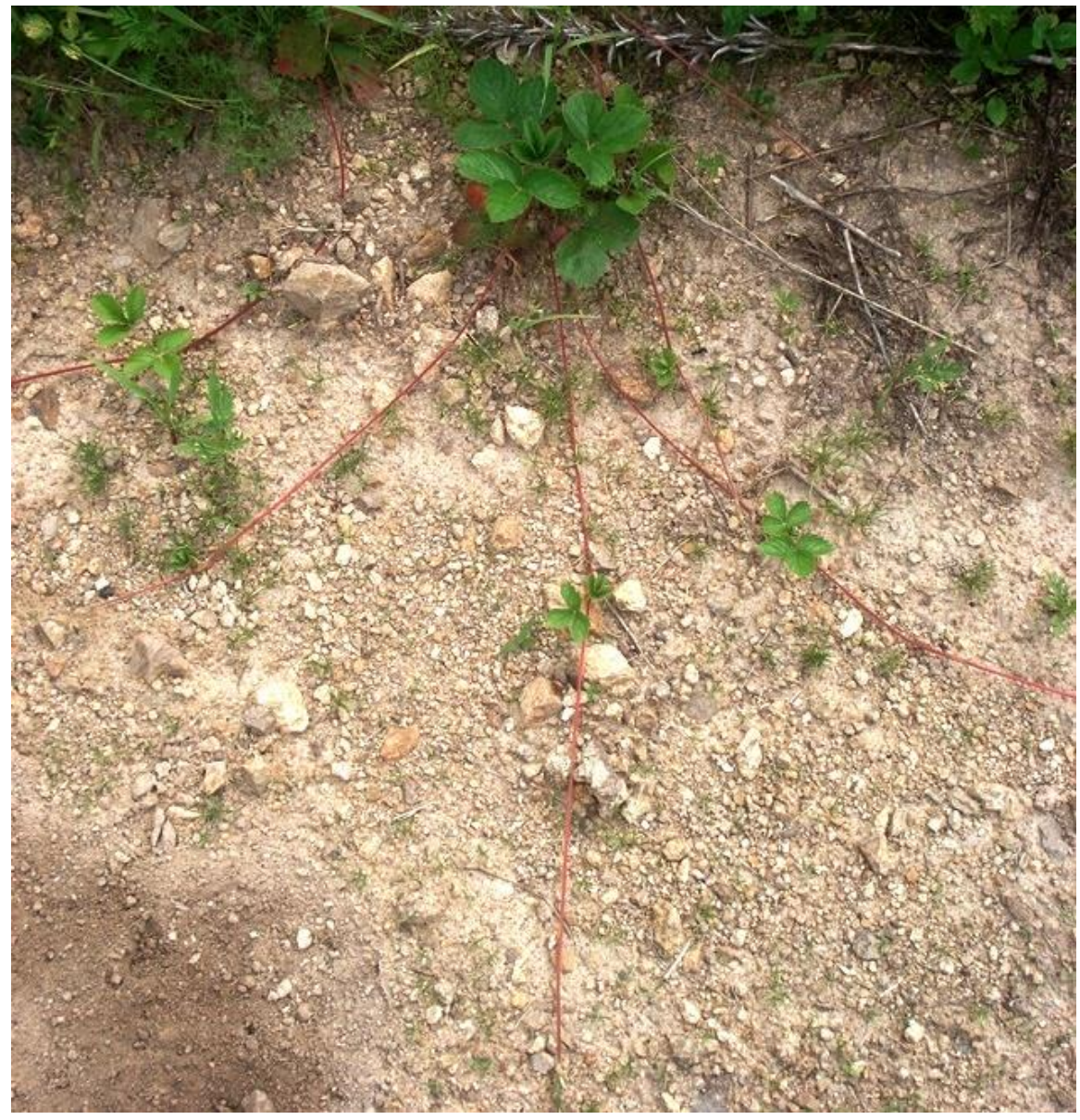

Рис. 22. Несколько столонов (усов), образовавшихся у одного экземпляра земляники восточной (фото В. Рыбаковой)
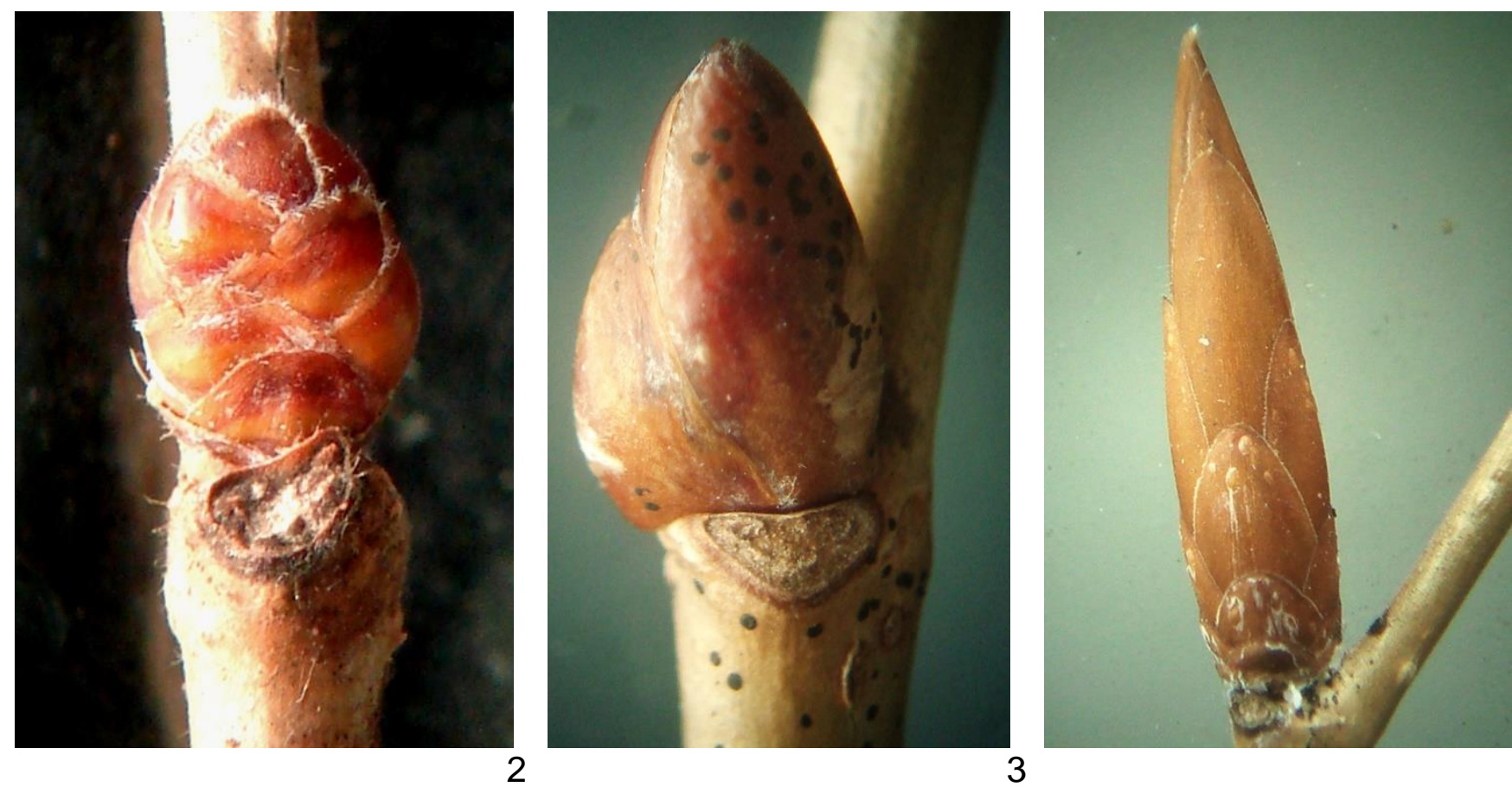

3

Рис. 23. Почки лещины разнолистной (CorylusheterophyllaFisch. exTrautv.) (1), липы амурской (TiliaamurensisRupr.) (2), граба сердцевидного (CarpinuscordataBlume) (3) (фотоА. Коляды) 


\title{
Литература
}

Бавтуто Г.А., Ерей Л.М. Практикум по анатомии и морфологии растений. Учебное пособие. Минск: Новое знание, 2002. $464 \mathrm{c.}$

Баранова М.В. Морфогенез луковиц лилий // Ботан. журн. 1971. Т. 56, N 11. С. 1593-1604.

Баркалов В.Ю. Лилиевые - LiliaceaeJuss. // Сосудистые растения советского Дальнего Востока. Т. 2. Л.: Наука, 1987. С. 359-376.

Буч Т.Г., Качура Н.Н., Швыдкая В.Д., Андреева Е.Р. Сорные растения Приморского края и меры борьбы с ними. Владивосток: Дальневосточное книжное издательство, 1981. 254 с.

Врищ Д.Л. Лилии Дальнего Востока и Сибири. Владивосток: Дальневосточное книжное издательство, $1972.111 \mathrm{c}$.

Игнатьева И.П., Андреева И.И. Метаморфозы вегетативных органов покрытосеменных. М.: КолосС, 2008. $38 \mathrm{c.}$

Коляда А.С., Коляда Н.А. Пути естественного вегетативного размножения семенных растений Дальнего Востока // Вестник КрасГАУ. 2011. № 1. С. 61-66.

Коровкин О.А. О структурно-функциональной специфике столона // Изв. ТСХА. 2013. Вып. 3. С. 4752.

Ракова М.В. Ореорхис раскидистый - Oreorchispatens (Lindl.) Lindl. // Биология редких сосудистых растений советского Дальнего Востока. Влаидвосток: ДВО АН СССР, 1990. С. 68-81.

Серебряков И.Г., Серебрякова Т.И. О двух типах формирования корневищ у травянистых многолетников // Бюл. МОИП. Отдел.биол. 1965. Т. 70, № 2.

Сосудистые растения советского Дальнего Востока / Под ред. С.С. Харкевича. Л.: Наука, 1985-1989. ТТ. 1-4. Спб.: Наука, 1991-1996. ТТ. 5-8.

Фёдоров Ал. А., Кирпичников М.Э., Артюшенко З.Т. Атлас по описательной морфологии высших растений. Стебель и корень. М.-Л.: Изд-во АН СССР, 1962. 352 с.

Шалыт М.С. Вегетативное размножение и возобновление высших растений и методы его изучения // Полевая геоботаника. Т. 2. М.;Л.: Изд-во АН СССР, 1960. С. 163-205.

Яковлев Г.П. Бобовые земного шара. Л.: Наука, 1991. 144 с.

\section{Local history material for studying the topic «Shoots metamorphoses» in the botany course in secondary school in Primorsky Krai}

\author{
V.V. Ribakova, A.S. Kolyada \\ Far Eastern Federal University. Branch in the Ussuryisk city (School of pedagogics)
}

The paper provides information on the shoot metamorphoses of vascular plants in Primorsky Krai, which can be used in teaching botany in a general education school.

Keywords: botany, shoot metamorphoses, local history material, PrimorskyKrai.

\section{Сведения об авторах:}

Рыбакова Владислава Вадимовна - студентка бакалавриата, кафредра естественнонаучного образования, Дальневосточный фредеральный университет, фрилиал в г. Уссурийске (Школа педагогики). 692500, Приморский край, е. Уссурийск, ул. Некрасова, 35; e-mail: thanetochka12@mail.ru.

Коляда Александр Степанович - доцент кафедры естественнонаучного образования, Дальневосточный фредеральный университет, филиал в г. Уссурийске (Школа педагогики), к.б.н., доцент; 692500, Приморский край, е. Уссурийск, ул. Некрасова, 35; e-mail: a.s.pinus@mail.ru. 
Основная масса растений, выращиваемых в школе - это выходцы из стран с тропическим и субтропическим климатом (фикусы, пальмы, бегонии), горных лесов тропиков (папоротники, орхидеи), сухих областей Юго-Восточной Африки (алоэ, молочаи, каланхоэ), сухих плато Мексики, Центральной и Южной Америки (кактусы, агавы).

Одни из них выращивают ради эффектных цветов, другие - из-за красивых листьев, третьи - для вертикального озеленения. Среди декоративно-цветущих растений в школах часто используются: пеларгонии, бегонии, сенполии. Из лиственно-декоративных применяются пальмы, папоротники, аспидистры. Из ампельных - камнеломки, традесканции, хлорофитум, плющ. Обширную группу занимают растения с сочными мясистыми стеблями или листьями причудливой формы - это суккуленты, произрастающие в жарких странах; они ценятся как неприхотливые и достаточно выносливые. Это разнообразные кактусы, молочаи, агавы, каланхоэ, толстянки и седумы(Клинковская и др., 2004).

При использовании комнатных растений в процессе обучения происходит фрормированиетаких умений, какспособность определять комнатные растения, составлять этикетки, разрабатывать методику применения комнатных растений на конкретных уроках раздела «Растения».

Легко размножающиеся комнатные растения можно использовать как раздаточный материал при проведении лабораторных работ. Правильно организованная работа скомнатными растениями дает следующие возможности учителю биологии (Методика..., 2020):

- познакомить учащихся с многообразием комнатных растений и их биологией;

- научить учащихся определять правильное научное название растений;

- изучить морфологические, анатомические и фризиологические особенности растений различных экологических групп;

- научить учащихся размножать растения;

- организовать опытническую работу учащихся, наблюдения по выявлению зависимости комнатных растений от их эколого-географического происхождения;

- провести внеклассную работу (кружок по комнатному цветоводству, вечера, конференции, викторины о комнатных растениях и т. д.).

При их подборе необходимо учитывать следующие требования:

1. В кабинете должны находиться растения различных экологических групп.

2. Растения обязательно должны использоваться в учебном процессе по биологии, а не служить только украшением кабинета.

3. Подбирать нужно растения, не требовательные к условиям выращивания, легко размножающиеся.

4. Недопустимо иметь вкабинете такие ядовитые растения, как паслен перечный (ядовитые ягоды), олеандр (ядовито все растение), пуансеттию (ядовит млечный сок).

Основные семейства и виды комнатных растений, используемых в школе(Асеев, 2015):

Семейство Пальмы (Арековые) - занимают одно из главных мест в оформлении школьных холлов и актовых залов - трахикарпус Форчуна, финик канарский, хамедореявысокая.

Семейство Лилейные - источник многочисленных и очень популярных декоративных растений - аспидистра высокая, драцена деремская, душистая, Сандерса, кордилина верхушечная, хлорофитум хохлатый.

Семейство Амарилиссовые - декоративны во время цветения - гиппеаструмсадовый, кливияоранжевая, эухарис крупноцветный.

Семейство Бегониевые - популярны как цветущие, так и лиственнодекоративные - бегония ампельная, вьюнковая, клубневая, королевская.

Семейство Геснериевые - высокодекоративные цветущие растения - сенполияфиалкоцветная, синнингиякрасивая.

Семейство Коммелиновые - наиболее устойчивые, ампельные - реопестрое, традесканция белоцветковая, приречная, зебрина висячая.

Семейство Ароидные - занимают одно из ведущих мест в озеленении школьных по- 
мещений - фрилодендрон лазящий, монстера привлекательная, диффренбахия пятнистая.

Суккуленты - благодатный объект для озеленения классных комнат, холлов, фойе агава американская, алоэ древовидное, мамиллярияВильда, опунция беловолосая, очиток Моргана, цереус перуанский.

Размещать комнатные растения лучше поэкологическим группам или поотношению ксвету, влаге, почве, чтобы облегчить уход заними. Для наиболее тенистых мест используются аспидистры, фратсии, фрикусы, циссусы. Среди комнатных растений есть виды, которые хорошо переносят сухой воздух - драцены, кактусы, кофейное дерево, лавр, монстеры, хлорофитумы.

Все растения кабинета должны иметь этикетку (рис. 1) размером $8 \times 5$ см изплотной бумаги ипаспорт. Вэтикетке указывается семейство, род, вид иродина растения. Готовую этикетку необходимо пропарафинить, чтобы она ненамокла (Магомедова М.А. и др., 2019).

\begin{tabular}{|l|l|}
\hline Семейство & - Лилейные \\
\hline Род & - Аспарагус \\
\hline Вид & - Аспарагус Шпренгера \\
\hline Родина & - субтропики Южной Африки \\
\hline
\end{tabular}

Рис. 1. Пример этикетки

На основе этикетки составляют паспорт растения, в котором указываются его биологические особенности, требования поуходу, литературные источники.

Учащимся можно дать индивидуальные задания по уходу за комнатными растениями, проведению опытов и наблюдений, подготовке сообщений и рефератов.

Примерное содержание рефератов:

\section{Бегония коралловая (Begoniacoralina)}

Род включает около 1000 видов, входящих в состав растительных сообществ тропиков (Вахтина, 1981). Большинство видов распространено в тропической зоне Южной Америки. Предпочитают тенистые влажные леса, селятся в долинах гор и на горных склонах. На втором месте по обилию видов - тропики Азии, особенно Восточные Гималаи, горные области Индии и Малайский архипелаг. Самая северная точка распространения рода находится на широте Пекина (КНР).

Наиболее часто встречающиеся в комнатной культуре виды бегонии: борщевиколистная - B. heracleifolia, коралловая - B. coralina, королевская - B. rex, краснолистная B. erythrophylla, манжетная - B. manicata.

Бегония коралловая в естественных условиях превышает в высоту 1,5 метра, но в комнатной культуре она значительно скромнее и редко вырастает выше метра. Листья бегонии очередные,достигают 7 см ширины и 20 см длины, имеют разнообразные тона зелёного цвета - от сочных, насыщенных оттенков до светлых. В период активного развития, летом,нижняя сторона окрашивается в стойкий глубокий малиновый тон, за что цветок и получил свое наименование (Чуб, 2006).

Уход за растением. В период весеннего роста растения нуждаются в азоте. При его недостатке бегонии отстают в развитии, листья становятся бледно-зелёными. При избытке азота растения плохо приспосабливаются к неблагоприятным условиям. Бегония не переносит слишком сырой почвы. Переувлажнение особенно опасно для нежной рассады, растения «задыхаются» от недостатка воздуха и могут погибнуть от корневой гнили. Субстрат должен быть влажным, но не мокрым. Следует избегать полива холодной водой, ниже $12^{\circ} \mathrm{C}$, чтобы не началось отмирание корней. В период цветения бегонии не должны испытывать недостатка влаги, иначе листья потеряют декоративность, а бутоны и цветки начнут опадать (Хессайон, 2018). 


\section{Маранта беложильчатая (Marantaleuconeura)}

Род включает 25 видов, распространенных в тропических дождевых лесах Америки. Встречаются на низких болотистых местах, по берегам водоёмов, вдоль рек и ручьев (Морщихина, 1982). Наибольшей популярностью пользуются в комнатной культуре виды маранты: Керховена (M. kerchoveana), Масанжа (M. massangeana), трехцветная (M. tricolor).

Маранта беложильчатая обладает клубневидным корнем, длина стебля может достигать 30 см. Черешки до 2 см длины, ширина листовой пластинки около 9 см, длина до 15 см; пластинки округло-эллиптические, в основании она сердцевидные. Верхняя поверхность тёмно-зёленая, её украшает бледно-зелёный рисунок и белые прожилки, нижняя сторона зеленовато-синяя либо бледно-красная(Чуб, 2006).

Уход за растением. Маранта нуждается в ярком, но рассеянном свете, её обязательно нужно защищать от прямых лучей солнца. Температура в летний период от $23^{\circ} \mathrm{C}$ до $25^{\circ} \mathrm{C}$, температура почвосмеси в горшке должна быть не менее $18^{\circ} \mathrm{C}$.Со второй половины осени и до последних весенних недель - от 18 до $20^{\circ} \mathrm{C}$.В весенне-летний период поливать нужно обильно, сразу же после того, как просохнет верхний слой почвосмеси. В холодное время года полив должен быть умеренным. Растение нуждается в повышенной влажности воздуха, в связи с этим его в течение всего года увлажняют из опрыскивателя отстоявшейся мягкой водой. Для повышения влажности в поддон насыпают влажный керамзит, а на него ставят цветочный горшок (Хессайон, 2018).

\section{Хлорофитум хохлатый (Chlorophytumcomosum)}

Род включает около 220 видов, большинство которых распространено в тропической Афррике, 20 видов встречается в Южной Африке, около 15 видов - на Мадагаскаре, по 1 - на юге Аравийского полуострова и на острове Сокотра, около 15 видов - в Индии, несколько видов - в Таиланде, Южном Китае, Австралии и Тасмании (Егорова, 1982).

Листья глянцевые, однотонные зелёные или имеют дополнительно светлую полосу по центру. Листовая пластинка довольно тонкая и собрана в пучки, которые напоминают хохолки.Весной происходит цветение, бутоны напоминают небольшие белые звёздочки.Обычно у растения только два яруса побегов, но при благоприятных условиях может появиться и третий.Стебли отсутствуют, листья растут прямо из корневой системы(Чуб, 2006).

Уход за растением. Хлорофитум хорошо растет на свету и в тени. Но больше всего ему нравится рассеянный свет. Одинаково хорошо ведет себя и в теплом, и прохладном помещениях. Он спокойно реагирует на большой диапазон температур воздуха. Единственное ограничение для зимнего периода - содержание в условиях не меньше $8^{\circ} \mathrm{C}$. Сухой воздух для него не помеха. Особенно когда после этого будет опрыскивание. Орошение следует проводить в летний период (Хессайон, 2018).

\section{Полезные свойства комнатных растений}

Некоторые из комнатных растений нейтрализуют вредные излучения от бытовых приборов. Это в основном относятся кактусы и суккуленты. Огромное количество растений также подавляют и уничтожают многие вредоносные микроорганизмы благодаря выделению особых летучих веществ - фитонцидов.

Цветотерапия является еще одним свойством комнатных растений. Присутствие цветущих комнатных растений в рабочей и жилой среде так же может влиять на расположение духа и настроение человека, при этом не последнее значение имеет их окраска. Известно, что холодные синие, голубые и зеленые тона успокаивают нервную систему, восстанавливают работоспособность. Теплые красные, оранжевые, желтые помогают проснуться, возбуждают, бодрят и снижают утомление, а присутствие розовых оттенков устраняет грусть и меланхолию, причем золотистая окраска уменьшает усталость глаз от работы на компьютере. Не последнюю роль играет и цветовая гамма листьев. Тёмно-зелёная и обычная зеленая листва действуют успокаивающе, светлая создает ощущение легкости, а пестрая способствует повышению работоспособности. Влияние на эмоциональное состояние человека оказывает даже форма кроны растений. Повышают работоспособность растения с раскидистой и пирамидальной кроной, успокаивают - с овальной и ампельной (Наумова и др., 2017). 
Таким образом, комнатные растения могут найти широкое применение во внекласной работе по биологии, играя, кроме того, значительную воспитательную роль.

\section{Литература}

Асеев В.Ю. Использование комнатных растений в школе // Рязанский государственный университет имени С.А. Есенина: вековая история как фундамент дальнейшего развития (100-летнему юбилею РГУ имени С.А. Есенина посвящается).материалы научно-практической конфреренции преподавателей РГУ имени С.А. Есенина по итогам 2014/15 учебного года. Ответственный редактор М.Н. Махмудов; Рязанский государственный университет имени С.А. Есенина, 2015. C. $462-464$.

Вахромеева А.А., Вилкова К.С. Комнатные растения как объект экологического воспитания // Проблемы экологического образования в XXI-м веке. Труды II Международной научной конференции (очно-заочной). 2018. С. 104-107.

Вахтина Л.И. Семейство Бегониевые (Begoniaceae// Жизнь растений. М.: Просвещение, 1981. Т. 5(2). С. 63-64.

Государственная программа Российской Федерации "Развитие образования" на 2013-2020 годы (утверждена Распоряжением Правительства РФ от 22 ноября 2012 г. №2148-р)

Даровских И.С. Внеурочная деятельность по истории: цели, организация, направления работы в современных условиях // Современные проблемы науки и образования. 2014. № 4. С 88.

Егорова Т.В. Семейство Асфоделовые (Asphodelaceae) // Жизнь растений. М.: Просвещение, 1982. T. 6. C. 127-148.

Клинковская Н.И., Пасечник В.В. Комнатные растения в школе. М.:Просвещение, 2004.

Колонтаев В.М.,Дробышева Л.М. Общая методика преподавания биологии. Тамбов: Изд-во ТГУ им. Г. Р. Державина, 2002. 229 с.

Магомедова М.А., Гаматаева Б.Ю., Магомедов Г.А., Касимова К.А., Алиева С.М. Организация и проведение научно-исследовательской работы с учащимися школ с использованием комнатных растений // Биоразнообразие и рациональное использование природных ресурсов. Материалы докладов VII Всероссийской научно-практической конференции, с международным участием. 2019. С. 176-180.

Методика использования комнатных растений в учебно-воспитательном процессе по биологии в школе [Электронный ресурс]. Режим доступа: https://bookonlime.ru/lecture/metodikaispolzovaniya-komnatnyh-rasteniy-v-uchebno-vospitatelnom-processe-po-biologii-v-6. Дата обращения: 15.11.2020.

Морщихина Е.Е. Порядок Имбирные (Zingiberales) // Жизнь растений. М.: Просвещение, 1982. Т. 6. C. 378-407.

Наумова Н.С., Ерофреев В.А. Влияние комнатных растений на микроклимат помещений и здоровье человека // Молодежь и наука. 2017. № 3. С. 37.

Педагогический энциклопедический словарь М: Большая российская энциклопедия, 2009. 527 с.

Решетникова Т.Б., Малыгина А.С. Применение комнатных растений в школе // Биология в школе. 2016. № 4. С. 64-74.

Решетникова Т.Б., Малыгина А.С. Применение комнатных растений в школе // Биология в школе. 2016. № 4. С. 64-74.

ХессайонД.Г. Все о комнатных растениях. Сорта. Уход. Дизайн. М.: Издательство АСТ, 2018. 192 с.

Чуб В. Мир комнатных растений Полная энциклопедия. М.: Эксмо, 2006. 416 с. 


\section{Useofindoorplantsintheeducationalprocessinsecondary schools}

\section{K.A. Shekhovtseva}

Far Eastern Federal University. Branch in the Ussuryisk city (School of pedagogics) discussed.

In the paper ways of using indoor plants in extracurricular activities and educational work are

Keywords: extracurricular activities, houseplants, houseplant care.

\section{Сведения об авторе:}

Шеховцева Карина Александровна - студентка бакалавриата, кафредра естественнонаучного образования, Дальневосточный фредеральный университет, фрилиал в г. Уссурийске (Школа педагогики). 692500, Приморский край, г. Уссурийск, ул. Некрасова, 35; E-mail: karina.shehovtseva@yandex.ru. 